\title{
Original Article \\ Northern Barbados accretionary prism: Structure, deformation, and fluid flow interpreted from 3D seismic and well-log data
}

\author{
Deniz Cukur, ${ }^{1}$ Gwang H. Lee, ${ }^{1, *}$ Jeong G. Um, ${ }^{1}$ Dae C. Kim ${ }^{1}$ And Jin H. Kim ${ }^{2}$ \\ ${ }^{1}$ Department of Energy Resources Engineering, Pukyong National University, Busan, Korea (email: \\ gwanglee@pknu.ac.kr) and ${ }^{2}$ Korea Institute of Geoscience and Mineral Resources, Daejon, Korea
}

\begin{abstract}
We reanalyzed 3D seismic reflection and logging-while-drilling data from the toe of the northern Barbados accretionary prism to interpret structure, deformation, and fluid flow related to subduction processes. The seafloor amplitude and coherence reveal an abrupt change in the thrust orientation from NNE at the thrust front and north and NNW about $5 \mathrm{~km}$ west of the thrust front. These thrust sets are separated by a triangular-shaped quiet area, which may represent a zone of low strength. The northeast-trending band of strong negative amplitude and high coherence in the décollement, known to be an interval of arrested consolidation, overlaps the quiet area, suggesting that the arrested consolidation may be related to the lack of thrust imbrication, and thus, vertical drainage for fluid in the accretionary prism. Fractal analysis of the décollement and top of the subducting oceanic basement indicates that the relief of the décollement correlates with the topography of the oceanic basement. Differential compaction of the underthrust sediment overlying the rugged oceanic basement, together with the basement faults that penetrate into the décollement probably caused relief or even faulting in the décollement.
\end{abstract}

Key words: Barbados accretionary prism, coherence, décollement, fractal analysis, seismic amplitude.

\section{INTRODUCTION}

Two fundamental processes at convergent margins are deformation and fluid flow (Moore \& Vrolijk 1992; LePichon et al. 1993; Moore et al. 1995). Deformation creates an accretionary prism and generates excessive fluids through sediment consolidation and fluid pathways through faulting (Moore \& Vrolijk 1992; Zhao et al. 1998). The excessive fluids control deformational styles and other fluid-rock interaction processes. Deformation and fluid flow also change sediment physical properties, which in turn cause changes in response to seismic reflection.

The Barbados accretionary prism (Fig. 1) at the eastern boundary of the Caribbean Plate is among the best-studied subduction zones in the world. It consists of extensively deformed and thrust-

${ }^{*}$ Correspondence.

Received 9 March 2008; accepted for publication 23 December 2008.

(C) 2009 The Authors

Journal compilation @ 2009 Blackwell Publishing Asia Pty Ltd faulted sediment of Quaternary to Miocene age, overriding the structural detachment or décollement. Subduction accretion has occurred at least since the Early Eocene (Speed \& Larue 1982). Data from the Deep Sea Drilling Project (DSDP) Leg 78A and Ocean Drilling Program (ODP) Legs 110,156 , and $171 \mathrm{~A}$ show that the décollement is initiated within a sediment layer with minimal strength and is progressively consolidated landward except for a few localized patches of low consolidation (Moore et al. 1998). The consolidation is attributed to shear-induced collapse of the sediment fabric (Moore et al. 1998) and progressive increase of tectonic loading to the west (Bangs et al. 1999). However, what controls the localized patches remains not well understood. The lowdensity anomaly in the décollement at ODP Site 1045 is located at the tip of a northeast-trending patch or band, defined by a strong negativepolarity reflection in 3D seismic data (Shipley et al. 1994). The northeast-trending band has been doi:10.1111/j.1440-1738.2009.00679.x 


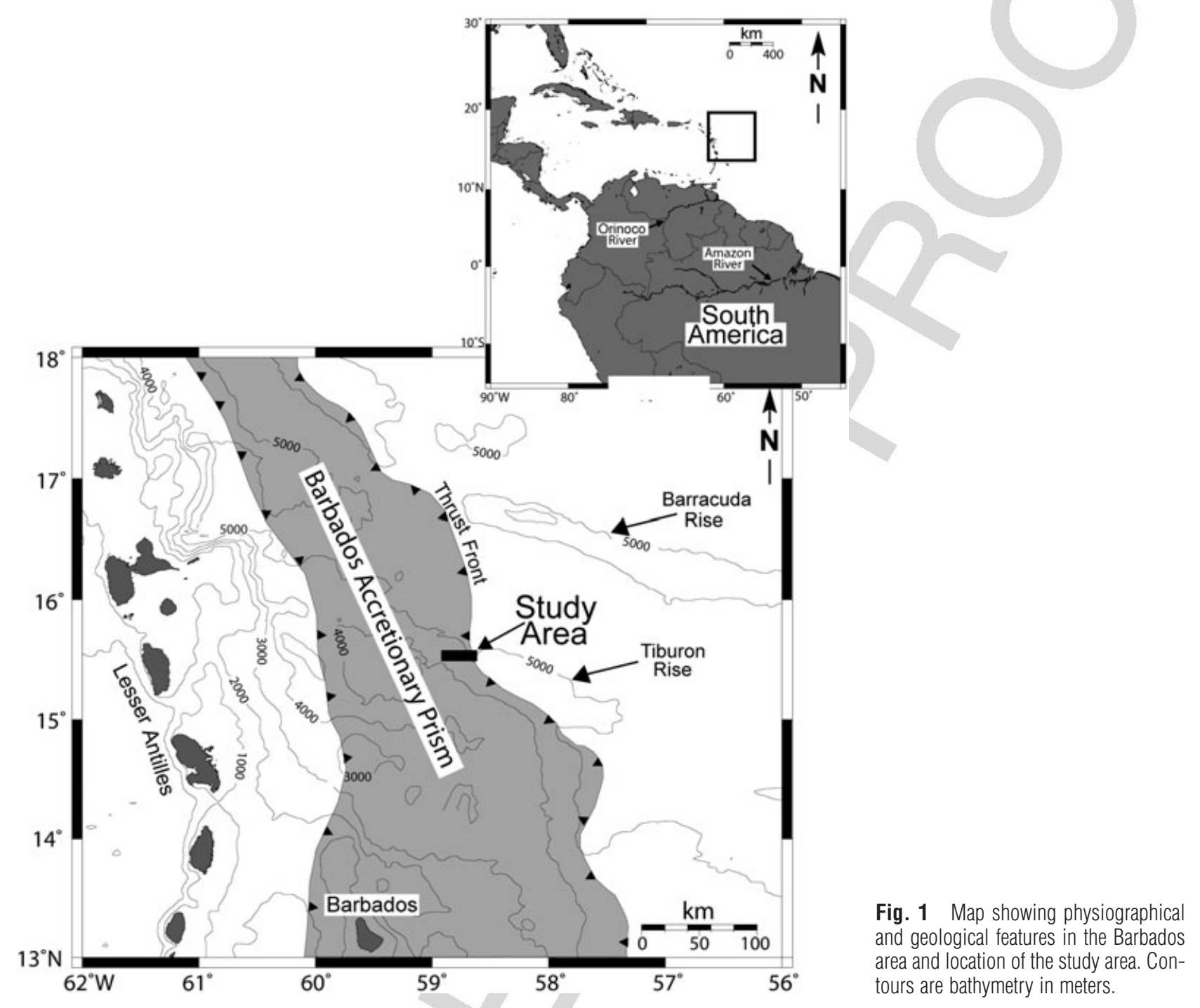

interpreted as an interval of arrested consolidation (Moore et al. 1998; Bangs et al. 1999; Zhao et al. 2000). The arrested consolidation may be achieved by features that reduce the permeability of the décollement zone conduit or its drainage to adjacent sediments, or by enhanced fluid flow from deep sources (Moore 2000).

The structure of the subducting oceanic basement may play an important role in the evolution of convergent margins (von Huene \& Scholl 1991). The type and thickness of sediment in the trench apparently determine whether the topography of the subducting oceanic basement influences the décollement (Moore \& Shipley 1988). At the toe of the Middle America Trench offshore Mexico, subducting normal fault blocks in the oceanic crust cause a ramp in the décollement (Moore \& Shipley 1988). The oceanic basement at the toe of the northern Barbados accretionary prism is charac- terized by structural highs with relief of about $300 \mathrm{~m}$ (Zhao et al. 2000), whereas the relief of the décollement appears to be very small. Nevertheless, the trends of the relief variance of the décollement and top of the oceanic basement largely mimic each other, suggesting that the roughness of the décollement is influenced by the structural trends of the oceanic basement (Wallace et al. 2003).

In this study, we reinterpreted and reanalyzed $3 \mathrm{D}$ seismic reflection and well-log data from the northern Barbados accretionary prism used in the previous studies mentioned above to revisit the issues regarding the nature of the northeasttrending amplitude band in the décollement. Our approach to data interpretation is not different from the earlier studies, but detailed analysis of the structure and attribute maps of the seafloor, décollement, and top of the subducting oceanic 
basement have provided new insights into the relationships between deformation and fluid flow. We also applied fractal dimensional analysis to quantitatively validate the correlation between the relief of the décollement and topography of the oceanic basement.

\section{GEOLOGIC AND TECTONIC SETTING}

The Barbados accretionary prism is the eastern leading edge of the Caribbean plate (Fig. 1) and has been growing eastward with respect to North and South America since at least the Eocene (Moore et al. 1998). The Atlantic oceanic lithosphere is being subducted westward $\left(282 \pm 18^{\circ}\right)$ under the Caribbean plate at a rate of $28 \pm 6 \mathrm{~mm} /$ year (Dixon et al. 1998). The subduction is evidenced by a well-defined Wadati-Benioff zone dipping westward to a depth of $200 \mathrm{~km}$ (Tomblin 1975). The Lesser Antilles Volcanic Arc, located about $300 \mathrm{~km}$ west of the prism toe, forms the active volcanic arc. The accretionary prism crops out in the island of Barbados (Moore et al. 1998).

The Barbados accretionary prism can be divided into northern and southern regions by the Tiburon Rise, which blocks the terrigenous sediment input from southern sources to the abyssal plain north of the rise (Moore et al. 1995). The southern accretionary prism is wide $(>200 \mathrm{~km})$, where a thick $(>5 \mathrm{~km})$ sequence of Plio-Pleistocene turbidite from the Orinoco submarine fan is being accreted, and it becomes narrow $(<125 \mathrm{~km})$ toward the north, where the sediment on the Atlantic Ocean floor is dominantly pelagic (Speed et al. 1984; Moore et al. 1998). These thickness and lithology variations at the toe of the accretionary prism have resulted in long-wavelength folds and widelyspaced thrusts in the southern region (Bangs et al. 1990), and closely-spaced thrusts in the northern region (Biju-Duval et al. 1982; Westbrook et al. 1984).

\section{DATA BASE}

Three-dimensional seismic reflection data (Fig. 2) used in this study consist of 205 inlines $(25 \mathrm{~km}$ long) and 1635 crosslines (5 km long). The seismic data set, acquired in 1992 (Shipley et al. 1994; Moore et al. 1995), covers $125 \mathrm{~km}^{2}$ of the trench and toe of the northern Barbados accretionary prism and the adjacent areas seaward of the deformation front, including DSDP sites from Leg 78A and ODP sites from Legs 110, 156, and 171A. The $3 \mathrm{D}$ seismic data were shot in an east-west direction at a line spacing of $50 \mathrm{~m}$ and interpolated to $25 \mathrm{~m}$ during processing. The common-mid-point spacing is $30 \mathrm{~m}$. A 52-channel, $650-\mathrm{m}$ streamer recorded shots from a 10-airgun, 38-L source array. The sampling rate is $4 \mathrm{~ms}$.

Initial processing of the 3D data was completed by Shipley et al. (1994) and Moore et al. (1995), following a standard 2D processing sequence, which included trace editing, common-midpoint sorting, frequency filtering, normal-moveout correction, and stacking. One line was then interpolated between each acquired line, resulting in a 25-m line spacing. Processing for the 3D data volume included one-pass 3D time migration and spherical spreading correction (Moore et al. 1995). Kingdom Suite ${ }^{\circledR}$ v7.6, OpendTect ${ }^{\circledR}$ v3.0.1, and Hampson-Russell ${ }^{\circledR}$ v4.0 were used for seismic and well-log data analysis and mapping.

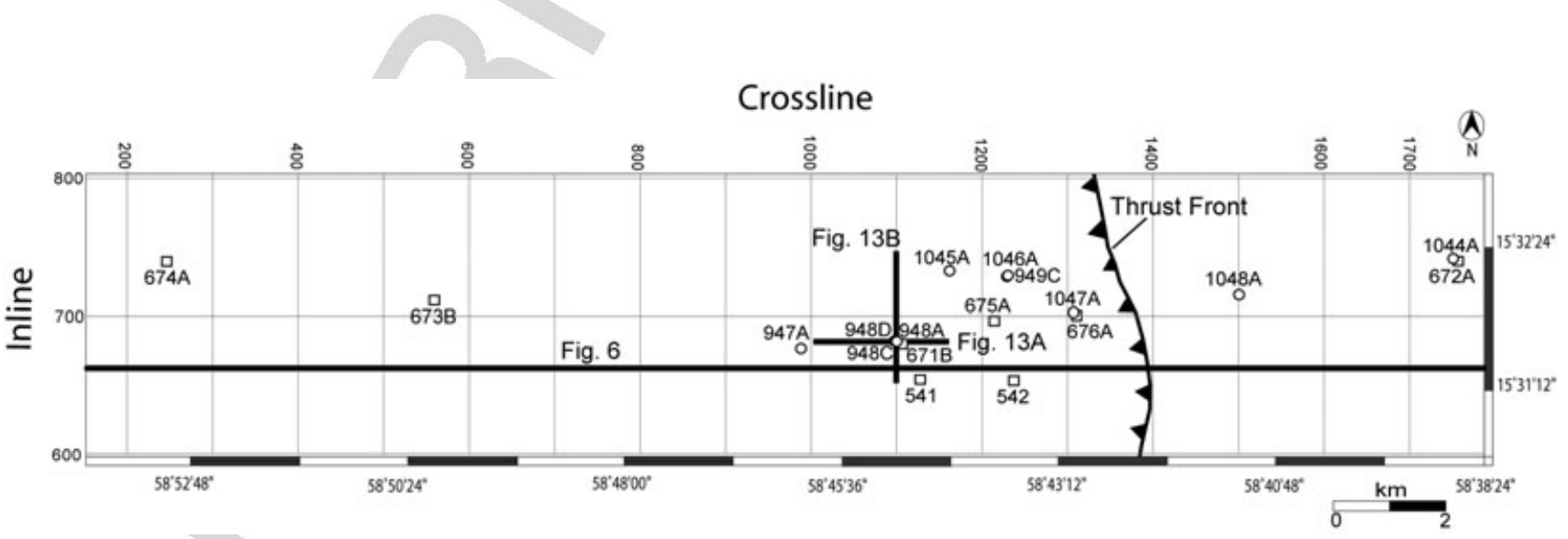

Fig. 2 Three-dimensional seismic data coverage and Ocean Drilling Program (ODP) holes. Heavy lines and respective figure numbers indicate seismic profiles shown in other figures. ODP holes from ODP Legs 156 and 171A (O), Deep Sea Drilling Project holes from Leg 78A and ODP holes from $\operatorname{Leg} 110(\square)$. 


\section{D. Cukur et al.}

Well-log data include logging-while-drilling (LWD) data from seven ODP holes: 947A and 948A from ODP Leg 156 (Shipboard Scientific Party 1995) and 1044A, 1048A, 1047A, 1046A, and 1045A from ODP Leg 171A (Moore et al. 1998) (Fig. 2). Holes 947A, 948A, 1045A, 1046A, and 1047A are located in the accretionary prism; among these, three $(948 \mathrm{~A}, 1045 \mathrm{~A}, 1046 \mathrm{~A})$ penetrated the décollement. Holes 1044A and 1048A are located seaward of the deformation front, penetrating the proto-décollement. DSDP sites (541, 542) from Leg 78A, ODP holes (671B, 672A, 673B, 674A, 675A, 676A) from Leg 110 and ODP holes (948C, 948D, 949C) from Leg 156 are also included in Figure 2.

The LWD data include spectral gamma-ray, resistivity, density, caliper, photoelectric effect, and neutron porosity. We used density logs to evaluate the consolidation state of the décollement and determine time-depth relationships at the ODP sites. The density log curves were imported into Kingdom Suite ${ }^{\circledR}$ for display and analysis. Kingdom Suite ${ }^{\circledast}$ and Hampson-Russell ${ }^{\circledast}$ were used for the synthetic-to-well tie from which the velocity field of the area was constructed.

\section{DATA ANALYSIS AND RESULTS}

\section{LOGGING-WHILE-DRILLING DATA}

Mapping the décollement and top of the oceanic basement requires reliable time-depth relationships. Figure 3 shows the procedure to construct the velocity field from the LWD and seismic data.

\section{Density and density porosity logs}

The proto-décollement zone was identified at $672 \mathrm{~A}$ and correlated to the décollement zone at $671 \mathrm{~B}$ (Shipboard Scientific Party 1988). The protodécollement zone is characterized by a pronounced low $\left(\sim 1.4 \mathrm{~g} / \mathrm{cm}^{3}\right)$ density anomaly with thickness of about $35 \mathrm{~m}$ (Fig. 4a). This low density anomaly continues to the décollement and diminishes gradually landward from $1048 \mathrm{~A}$ to $948 \mathrm{~A}$ except for $1045 \mathrm{~A}$.

Density, acoustic, and neutron logs are porosity logs because of their sensitivity to porosity. Acoustic logs were not acquired during ODP Legs 156 and $171 \mathrm{~A}$ because the available devices were unreliable in sediments with velocities $<2000 \mathrm{~m} / \mathrm{s}$. Neutron porosity logs are most accurate in formations with porosities not exceeding 40\% (Theys

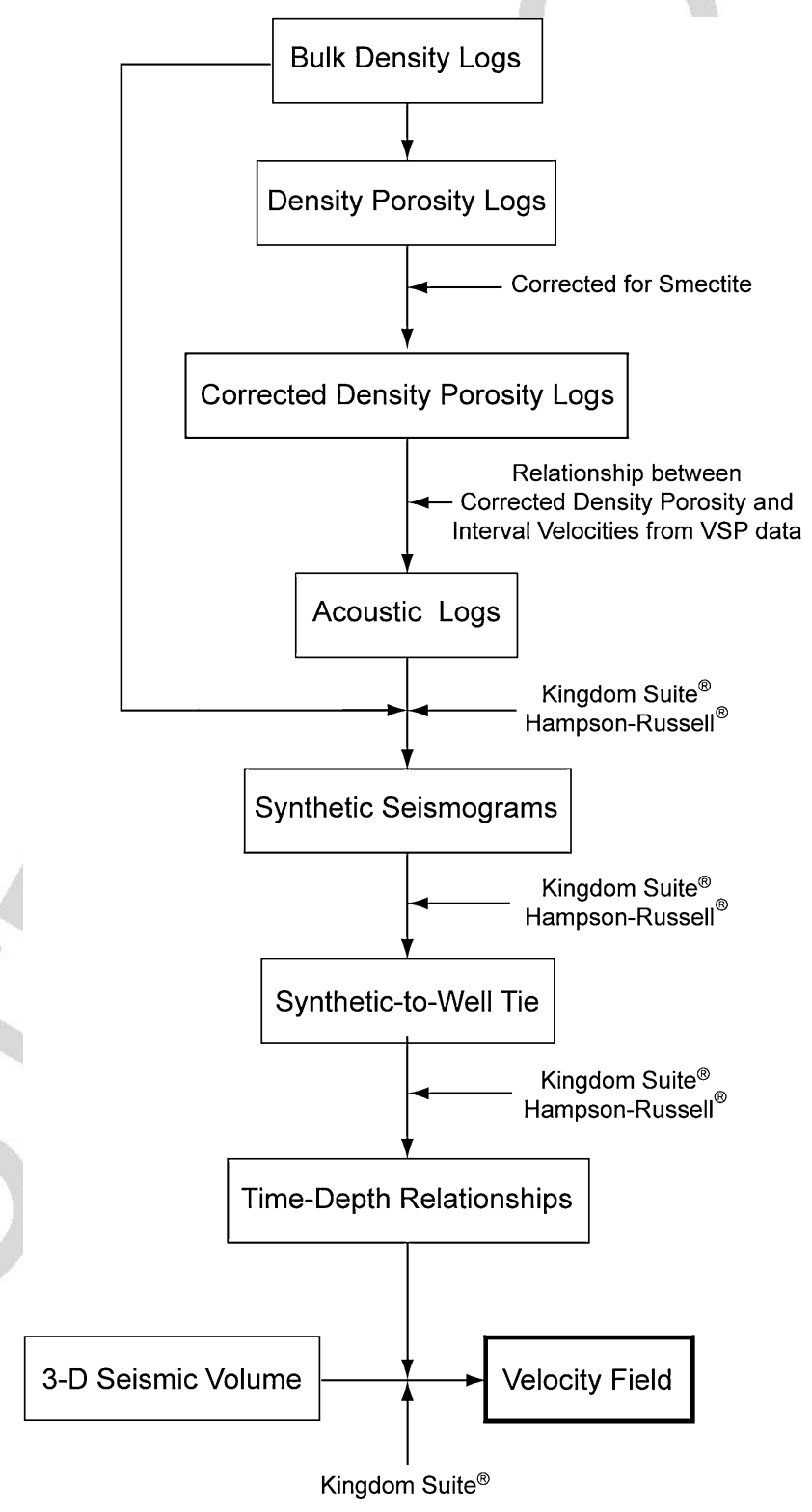

Fig. 3 Flow diagram illustrating the procedure to construct the velocity field of the study area.

1991). However, neutron porosities in the Barbados accretionary prism are as high as $70 \%$, resulting in noisy and scattered data. Thus, we used bulk density to estimate porosity using the following equation (Asquith 1982):

$$
\phi=\left(\rho_{m a}-\rho_{b}\right) /\left(\rho_{m a}-\rho_{f}\right)
$$

where $\phi=$ porosity, $\rho_{m a}=$ matrix density, $\rho_{b}=$ bulk density, and $\rho_{f}=$ fluid density. Median matrix densities (Table 1) measured from the cores taken at the ODP sites (Shipboard Scientific Party 1998) were used for matrix density. The density of fluid was assumed to be $1.02 \mathrm{~g} / \mathrm{cm}^{3}$ (Erickson \& Jarrard 1999). 
(a)

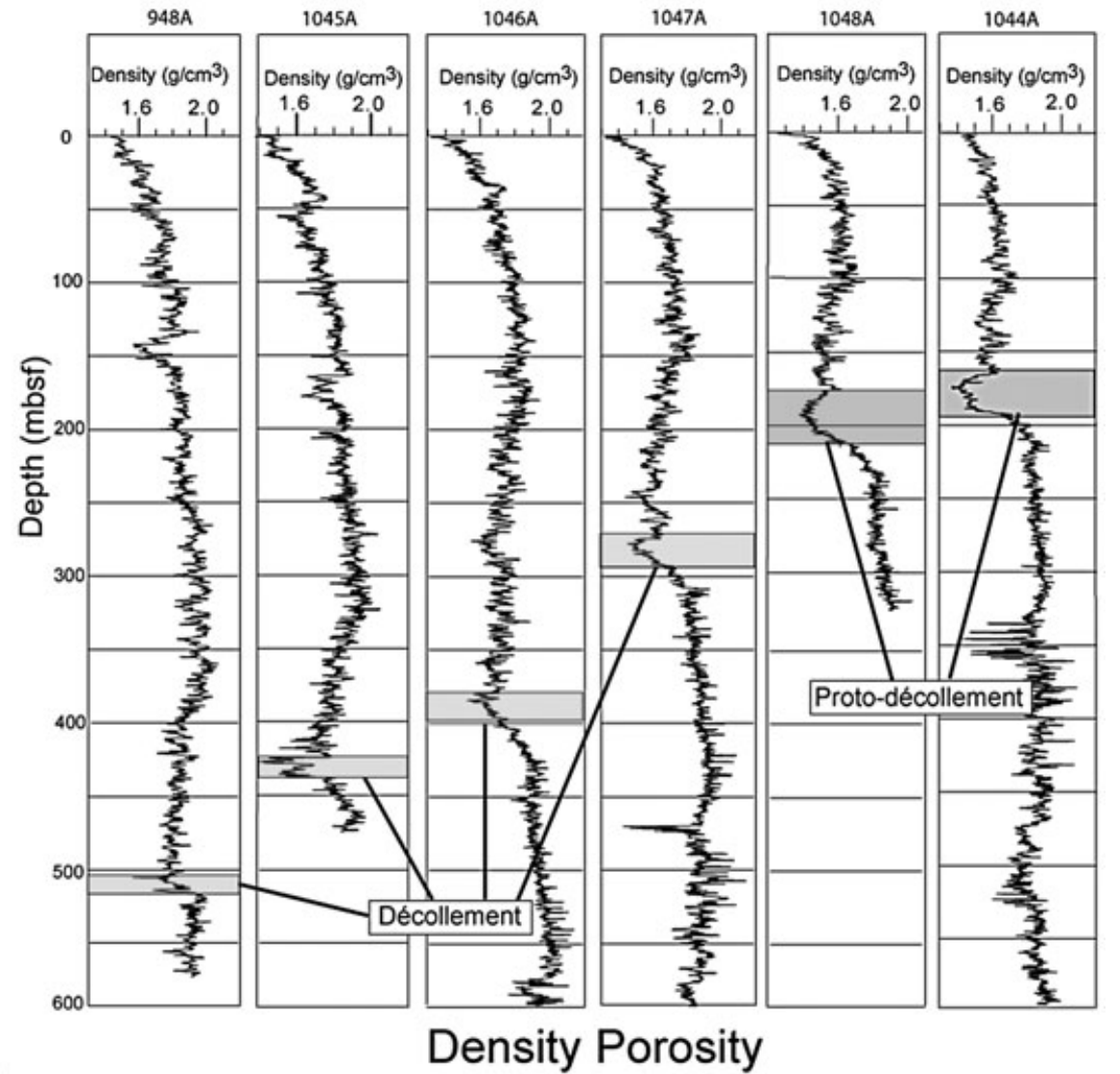

Fig. 4 (a) Logging-while-drilling (LWD) bulk density logs for Ocean Drilling Program holes 948A, 1045A, 1046A, 1047A, 1048A, and 1044A (Shipboard Scientific Party 1995; Moore et al. 1998). The proto-décollement zone has a pronounced low-density anomaly at 1044A and $1048 \mathrm{~A}$, but the anomaly progressively diminishes landward except at $1045 \mathrm{~A}$, where the décollement zone is believed to be under arrested consolidation (Moore etal. 1998). (b) Density porosity computed from bulk density. (c) Density porosity and smectite-corrected density porosity. Smectite-corrected density porosities are slightly lower than the density porosities. (d) Acoustic logs converted from velocity logs, which were constructed from the relationship between the interval velocities (Table 3) (Moore etal. 1998) and the smectitecorrected density porosities. mbsf, meters below seafloor. Figure 2 shows well location.

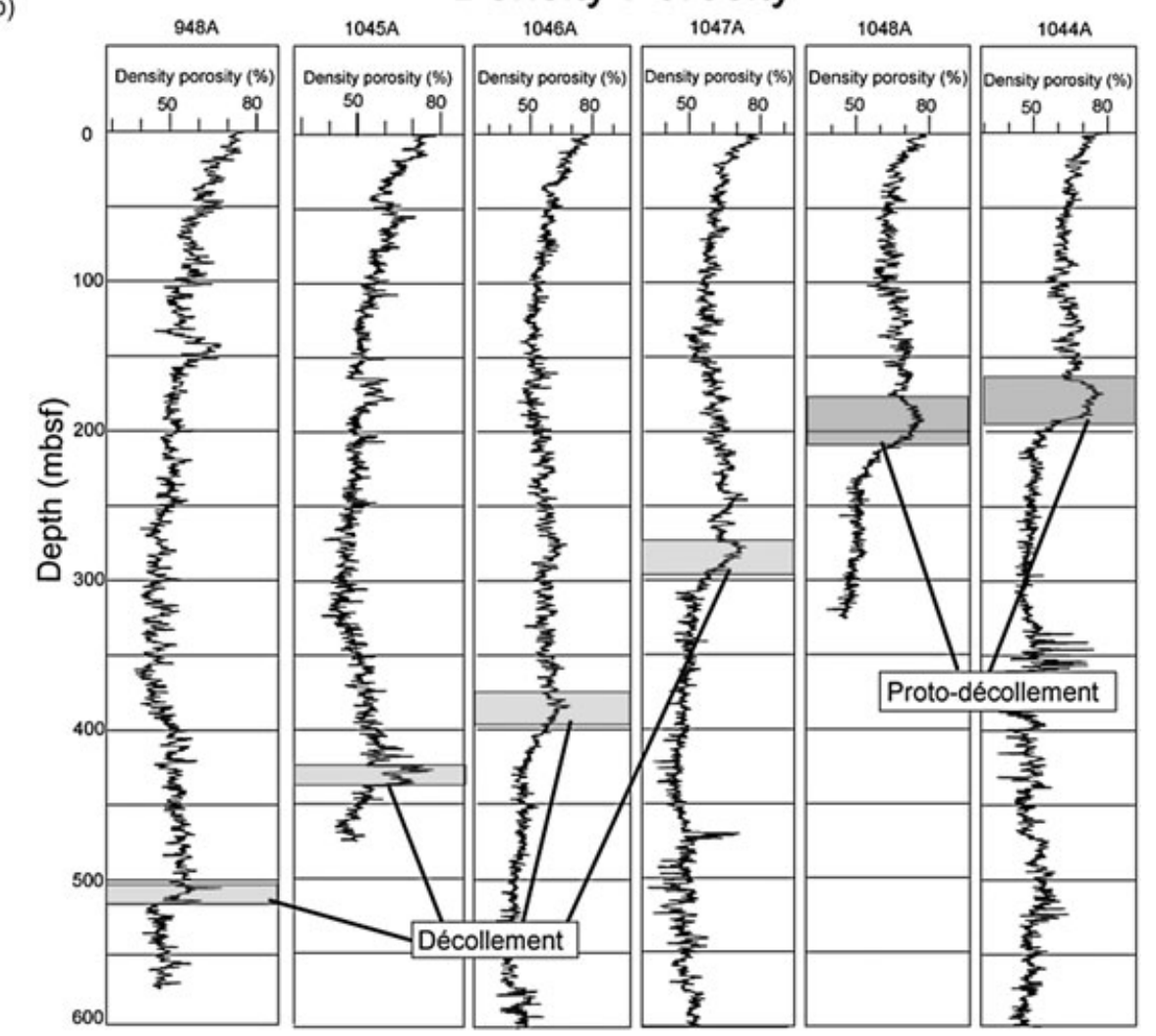

4 
6 D. Cukur et al.

(c) Density Porosity and Smectite-Corrected Porosity

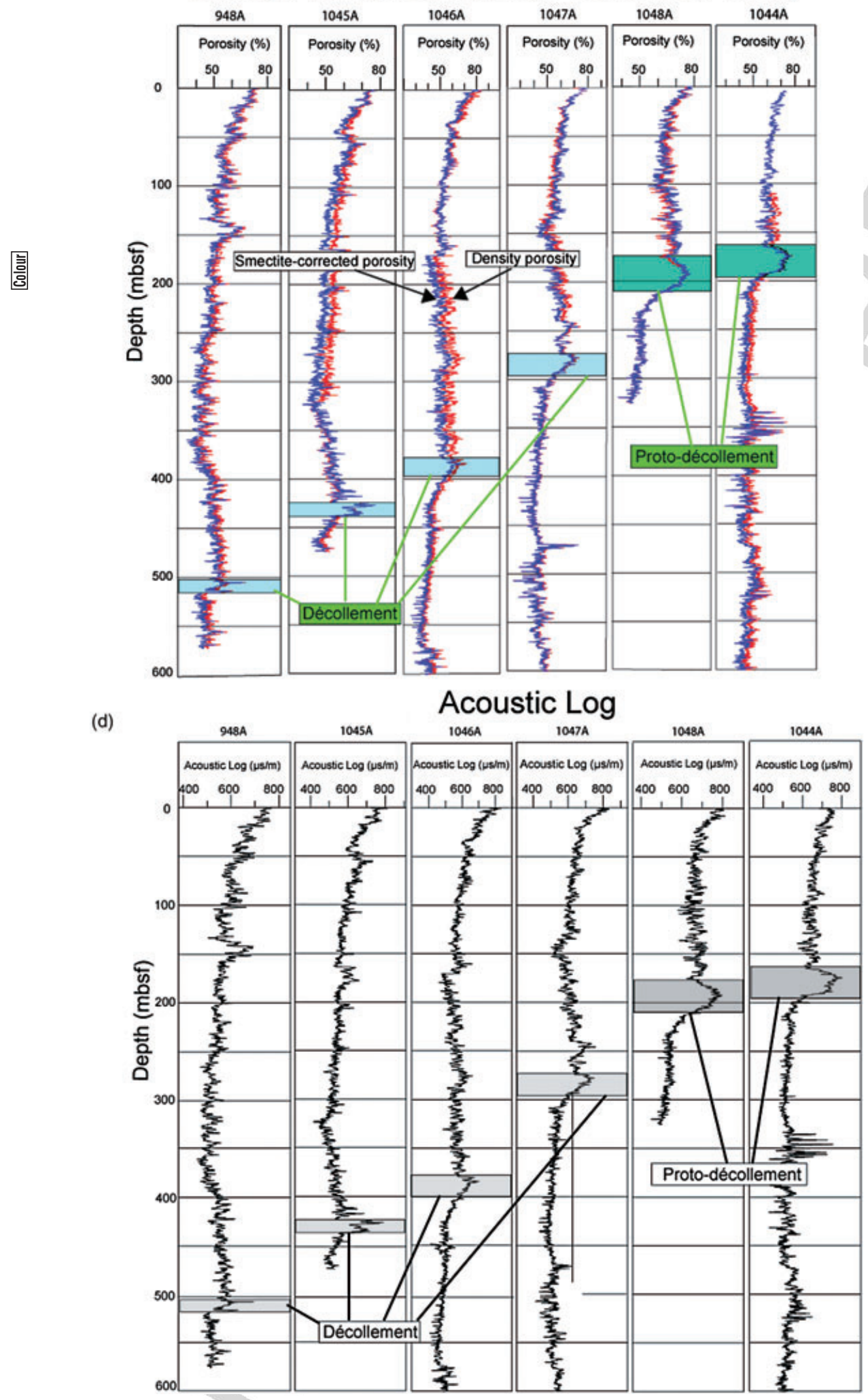

Fig. 4 Continued. 
Table 1 Median matrix densities of cored sediments at ODP sites in the Barbados accretionary prism (Shipboard Scientific Party 1998) used to compute density porosity

\begin{tabular}{lc}
\hline ODP site & $\begin{array}{c}\text { Median matrix density } \\
\left(\rho_{\text {ma }}\right)\left(\mathrm{g} / \mathrm{cm}^{3}\right)\end{array}$ \\
\hline 671,948 & 2.71 \\
672 & 2.64 \\
676 & 2.66 \\
949 & 2.66 \\
\hline
\end{tabular}

ODP, Ocean Drilling Program; $\rho_{m a}$, matrix density.

The density porosity is about $75 \%$ at $1044 \mathrm{~A}$ and $1048 \mathrm{~A}$ in the proto-décollement zone and decreases landward along the décollement from $70 \%$ at $1047 \mathrm{~A}$ to $65 \%$ at $1046 \mathrm{~A}$, and to $55 \%$ at $948 \mathrm{~A}$ (Fig. 4b), exhibiting the same trend as that of the bulk density. The density porosity at $1045 \mathrm{~A}$ located further landward from 1046A is $70 \%$.

\section{Smectite-corrected density porosity}

Smectite is abundant in the Barbados accretionary prism (Capet et al. 1990; Tribble et al. 1990). Because clay minerals such as smectite contain a substantial amount of interlayer water, the matrix density of clay-rich sediments, determined from dried samples, can be too high. Erickson and Jarrard (1999) constructed the smectite block model (their figure 3) for the LWD sites in the study area in which smectite contents (wt\%) were converted to matrix densities using the equation:

$$
\begin{gathered}
\rho_{m a}=\% \text { smectite }\left(2.1 \mathrm{~g} / \mathrm{cm}^{3}\right) / 100 \\
+(100-\% \text { smectite })\left(2.8 \mathrm{~g} / \mathrm{cm}^{3}\right) / 100
\end{gathered}
$$

Smectite and all other minerals were assumed to have a density of $2.1 \mathrm{~g} / \mathrm{cm}^{3}$ and a median density of $2.8 \mathrm{~g} / \mathrm{cm}^{3}$, respectively (Erickson \& Jarrard 1999). We followed Erickson and Jarrard's (1999) method to determine the matrix densities corrected for smectite (Table 2), and then the corrected matrix densities were used in Equation 1 to compute the porosities corrected for smectite (Fig. 4c). The smectite-corrected porosities are slightly lower than the density porosities by less than $5 \%$ at all holes.

\section{Acoustic logs from smectite-corrected density porosity}

The only available acoustic log is a standard wireline $\log$ from $948 \mathrm{C}$. The quality of this log, however, is not reliable, especially at the décollement zone because of the poor borehole condition (Shipboard
Scientific Party 1995). Thus, we obtained the relationship (Table 3, Fig. 5) between the interval velocities at 948D and 949C from the vertical seismic profiling data (Moore et al. 1997; Peacock et al. 1997) and the smectite-corrected porosities to create velocity logs from the smectite-corrected porosities. The relationship between the interval velocities and smectite-corrected porosities is given by Equation 3:

$$
\begin{aligned}
& \text { Interval velocity }=3464 \\
& \times \exp (-1.33 \cdot \text { Porosity })
\end{aligned}
$$

The velocity logs were converted to acoustic logs (Fig. 4d). Synthetic seismograms were constructed from the acoustic and bulk density logs and tied with seismic traces at the ODP sites. The synthetic-to-well tie yielded the velocity structure at the ODP sites and these velocities were interpolated between the ODP sites and extrapolated across the area to obtain the regional velocity field for the $3 \mathrm{D}$ seismic data. The velocity field was used for the time-to-depth conversion of the décollement and top of the oceanic basement. The lithologies above the décollement are fairly uniform terrigenous muds (Shipley et al. 1998), and thus, the depth of the décollement determined from the regional velocity is probably reliable. Because the underthrust sediments are not severely deformed and the oceanic basement is very rugged, the relief of the top of the oceanic basement determined from the regional velocity is also probably reliable.

\section{SEISMIC REFLECTION DATA}

Structural features and seismic characteristics of the seafloor, décollement, and top of the oceanic basement are shown in inline 662 (Fig. 6). The gentle seafloor shows undulation and hints of faulting. The negative-polarity décollement reflection separates almost reflection-free intervals above and subhorizontal underthrust sedimentary sequences below. The top of the oceanic basement is identified as a high-amplitude, rugged reflector. The basement is dissected by numerous faults. Some large faults cut across the underthrust sediment and extend to the décollement. Small bumps or steps are seen locally at the décollement where these faults terminate. Structures in the underthrust sediment are mostly secondary, controlled by those in the oceanic basement.

The seafloor, décollement/proto-décollement, and top of the oceanic basement were mapped 
Table 2 Smectite contents from the smectite block model of Erickson and Jarrard (1999) and matrix densities corrected for smectite

\begin{tabular}{lcccccc}
\hline & Zone 1 & Zone 2 & Zone 3 & Zone 4 & Zone 5 & Zone 6 \\
\hline Smectite content $(\%)$ & 25 & 52 & 36 & 39 & 41 & 40 \\
$\rho_{\text {ma }}$ corrected for smectite $\left(\mathrm{g} / \mathrm{cm}^{3}\right)$ & 2.625 & 2.436 & 2.548 & 2.527 & 2.513 & 2.520 \\
\hline
\end{tabular}

Six zones were defined, based on resistivity and density logs.

$\rho_{\text {ma }}$, matrix density.

Table 3 Interval velocities at holes 948D and 949C from vertical seismic profiling data (Moore et al. 1998) and average interval porosities from smectite-corrected density porosities

\begin{tabular}{lccc}
\hline Hole & $\begin{array}{c}\text { Depth range (meters } \\
\text { below seafloor) }\end{array}$ & $\begin{array}{c}\text { VSP interval velocity } \\
(\mathrm{m} / \mathrm{s})\end{array}$ & $\begin{array}{c}\text { Average interval } \\
\text { porosity (from } \\
\text { smectite-corrected } \\
\text { density-based porosity) }\end{array}$ \\
\hline $948 \mathrm{D}$ & $157-248$ & 1750 & 0.48 \\
& $248-313$ & 1970 & 0.43 \\
$949 \mathrm{C}$ & $313-405$ & 2020 & 0.43 \\
& $405-460$ & 1810 & 0.49 \\
& $100-177$ & 1750 & 0.50 \\
& $177-272$ & 1700 & 0.49 \\
\hline
\end{tabular}

VSP, vertical seismic profiling.

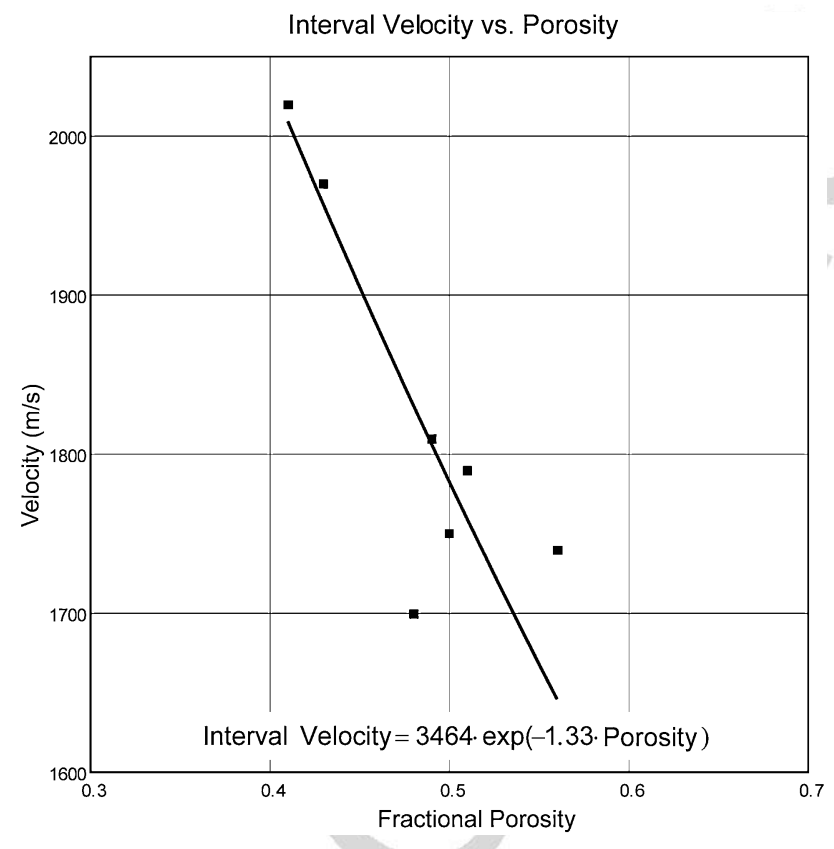

Fig. 5 Plot of the interval velocities (Moore et al. 1998) (Table 3) at Ocean Drilling Program holes 948D and 949C and the smectite-corrected porosities and their relationship.

(Figs 7-9). Reflection amplitude and coherence were also extracted and mapped for the seafloor and décollement/proto-décollement. Seismic coherence can highlight discontinuities such as (C) 2009 The Authors Journal compilation (c) 2009 Blackwell Publishing Asia Pty Ltd faults and lateral facies changes better than conventional seismic amplitude (Bahorich \& Farmer 1995).

\section{Seafloor}

The water depths (Fig. 7a) of the study area range from about 4500 to greater than $5000 \mathrm{~m}$ from west to east. The amplitude (Fig. 7b) and coherence (Fig. 7c) of the seafloor reveal at least two sets of active faults in the accretionary prism, characterized by low-amplitude and low-coherence linear features: north- and NNW-trending faults immediately landward of the deformation front and NNE-trending faults in the western central part of the area. A triangular-shaped area with no distinct faults, marked as T, is seen between these two fault sets in the central part of the area. This triangularshaped quiet area is characterized by homogeneous and high coherence.

\section{Décollement/proto-décollement}

The décollement/proto-décollement deepens gradually landward from less than 5200 to greater than $5800 \mathrm{~m}$ (Fig. 8a). The amplitude of the décollement (Fig. 8b) reveals a northeast-trending band of strong negative-polarity amplitude with sharp 
Fig. 6 (a) Inline showing structural features and seismic characteristics of the seafloor, décollement, and top of the oceanic basement. (b) Line-drawing interpretation of (a). The negativepolarity décollement reflection separates the almost reflection-free accretionary prism above and subhorizontal underthrust sediment below. The oceanic basement is characterized by grabenand-rift topography. Large basement faults, cutting across the underthrust sediment, extend into small bumps or steps in the décollement, suggesting that they are penetrative. Figure 2 shows location.
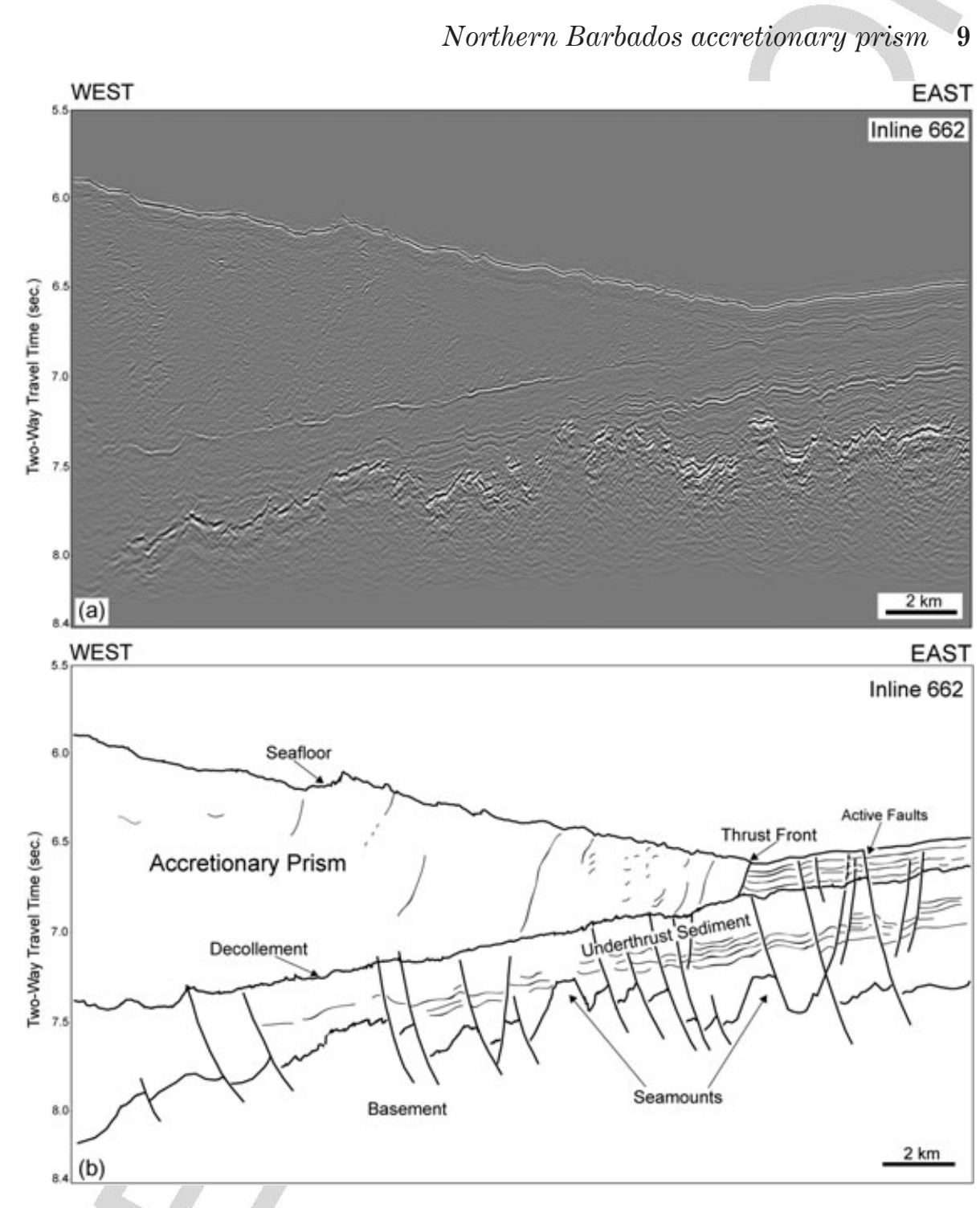

edges in the central part of the area. Much of the southern part of the amplitude band appears to coincide with the triangular-shaped quiet area in the seafloor. Part of the southeastern edge of the amplitude band trends NNW, largely coincident with the eastern boundary of the triangularshaped area. A distinct, northeast-trending band of low amplitude is also seen in the western part of the area.

The coherence of the décollement/protodécollement (Fig. 8c) shows characteristics almost identical to the amplitude. The high negativeamplitude band corresponds to the homogeneous and high-coherence band. The southwestern corner of the high-coherence band is cut by a very thin northeast-trending low-coherence anomaly, indicated by an arrow, which is not very obvious in the amplitude map. This low-coherence feature appears to follow the western edge of the triangular-shaped area on the seafloor. The northeast-trending low-amplitude band in the western part of the area is also characterized by low coherence.

\section{Top of oceanic basement}

The oceanic basement is very rugged, dissected by numerous faults and punctuated by seamounts (Fig. 6). The depths of the oceanic basement (Fig. 9a) range from less than $5300 \mathrm{~m}$ seaward of the deformation front to greater than $6500 \mathrm{~m}$ in the westernmost part of the area. The structure of the oceanic basement, characterized by horstand-graben topography with relief of up to about $450 \mathrm{~m}$, greater than previously reported, is dominated by NNE-trending closely-spaced normal faults. Most of these faults dip seaward; landwarddipping faults are also seen locally. The 3D surface map also reveals prominent structural highs and nearly circular seamounts (Fig. 9b). The coherence 


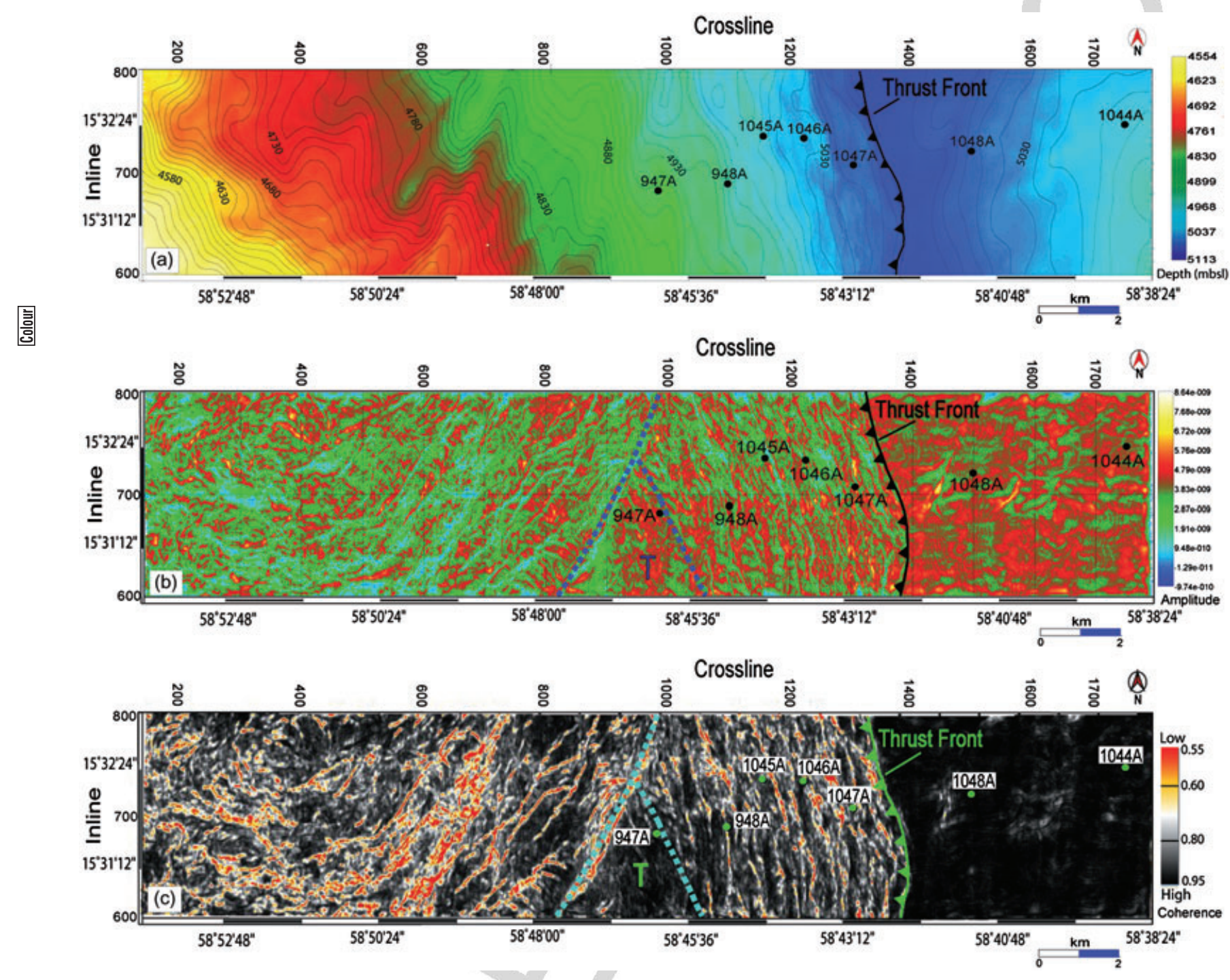

5 Fig. 7 (a) Bathymetry, (b) amplitude, and (c) coherence of the seafloor. The amplitude and coherence reveal two sets of faults: north- and NNW-trending faults near the deformation front and NNE-trending faults in the western central part of the area. A triangular-shaped quiet area (T), probably representing a zone of low strength, separates the two fault sets. mbsl, meters below sealevel.

map (Fig. 9c) shows a small high-coherence area, marked as HC, lying below the northeast-trending band in the décollement and the southwestern part of the triangular-shaped quiet area in the seafloor.

FRACTAL PARAMETERS OF THE DÉCOLLEMENT AND TOP OF THE OCEANIC BASEMENT

\section{Roughness-length method}

We examined spatial relationships between the décollement and top of the oceanic basement using fractal parameters estimated from the roughnesslength method (Malinverno 1990) (Fig. 10). The roughness-length method can remove a linear trend of non-stationary profiles, such as the depths (C) 2009 The Authors Journal compilation (c) 2009 Blackwell Publishing Asia Pty Ltd of the décollement and top of the oceanic basement, and produce fractal parameter estimates that are the same as those obtained from the corresponding stationary profile (Kulatilake \& Um 1999).

The following relationship (Malinverno 1990) can be applied to self-affine fractal time/space series such as surface topography (Feder 1988; Malinverno 1990):

$$
\begin{gathered}
s(w)=A w^{H} \\
\ln s(w)=\ln A+H \ln w
\end{gathered}
$$

where $s(w), w, H$, and $A$ are the standard deviation of the profile height, spanning length of the profile, 


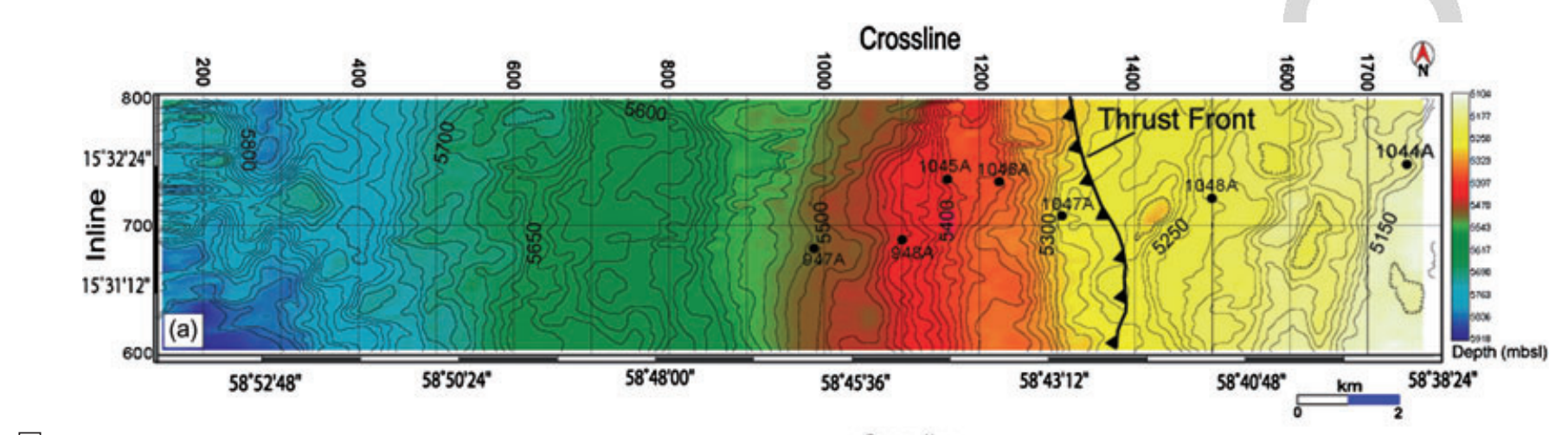

言
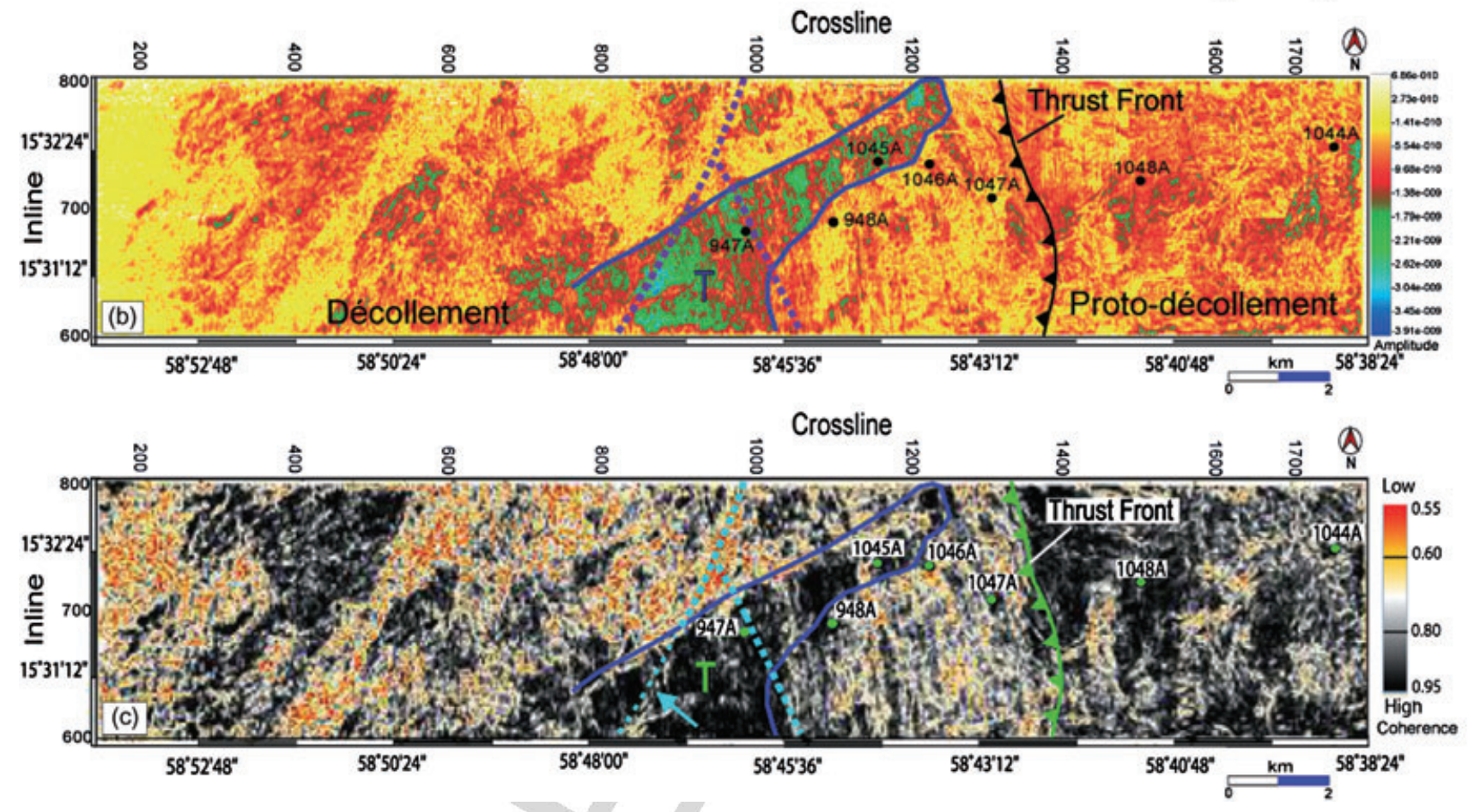

6 Fig. 8 (a) Depth, (b) amplitude, and (c) coherence of the décollement/proto-décollement. The northeast-trending band of strong negative amplitude and high coherence, known to be an interval of arrested consolidation, overlaps the triangular-shaped quiet area (T) in the seafloor, suggesting that the arrested consolidation may be related to the lack of thrust imbrication and thus vertical drainage for fluid in the accretionary prism. mbsl, meters below sealevel. Arrow in (c) indicates a very thin low-coherence anomaly which is not very obvious in the amplitude map.

Hurst exponent, and a proportionality constant, respectively. $H(0<H<1)$ and $\ln A$ are the slope and intercept, respectively, of the plot between $\ln s(w)$ and $\ln w$. Different $A$ values are possible for the same profile, depending on the unit (e.g. $100 \mathrm{~m}$ ) for $w$. A depends on the scale and can represent the amplitude of a roughness profile at different scales. $H$ and the fractal dimension, $D$, are related for linear self-affine profiles by:

$$
H=2-D
$$

Either $H$ or $D$ captures the auto-correlation structure of the profile. The fractal parameters, $D$ and $A$, can quantify stationary roughness of profiles and decrease with decreasing stationary roughness (Kulatilake \& Um 1999).
In order to obtain accurate estimates for $A$ and $H$, it is necessary to check the linear relationship between $\ln w$ and $\ln s(w)$ in Equation 5. In the relationship between $s(w)$ and $w, s(w)$ is calculated as the root-mean-square (RMS) value of the profile height residuals on a linear trend fitted to the sample points in the window of length $w$. A trend is subtracted to avoid overestimating roughness in small windows. The local linear trend in the window can be estimated by least-squares regression or by taking the line that connects the end points in the window. Because the estimation of a trend involves estimating two parameters, slope $(H)$ and intercept $(\ln A)$, from the data, the RMS roughness is calculated using $m_{i}-2$ degrees of freedom: 

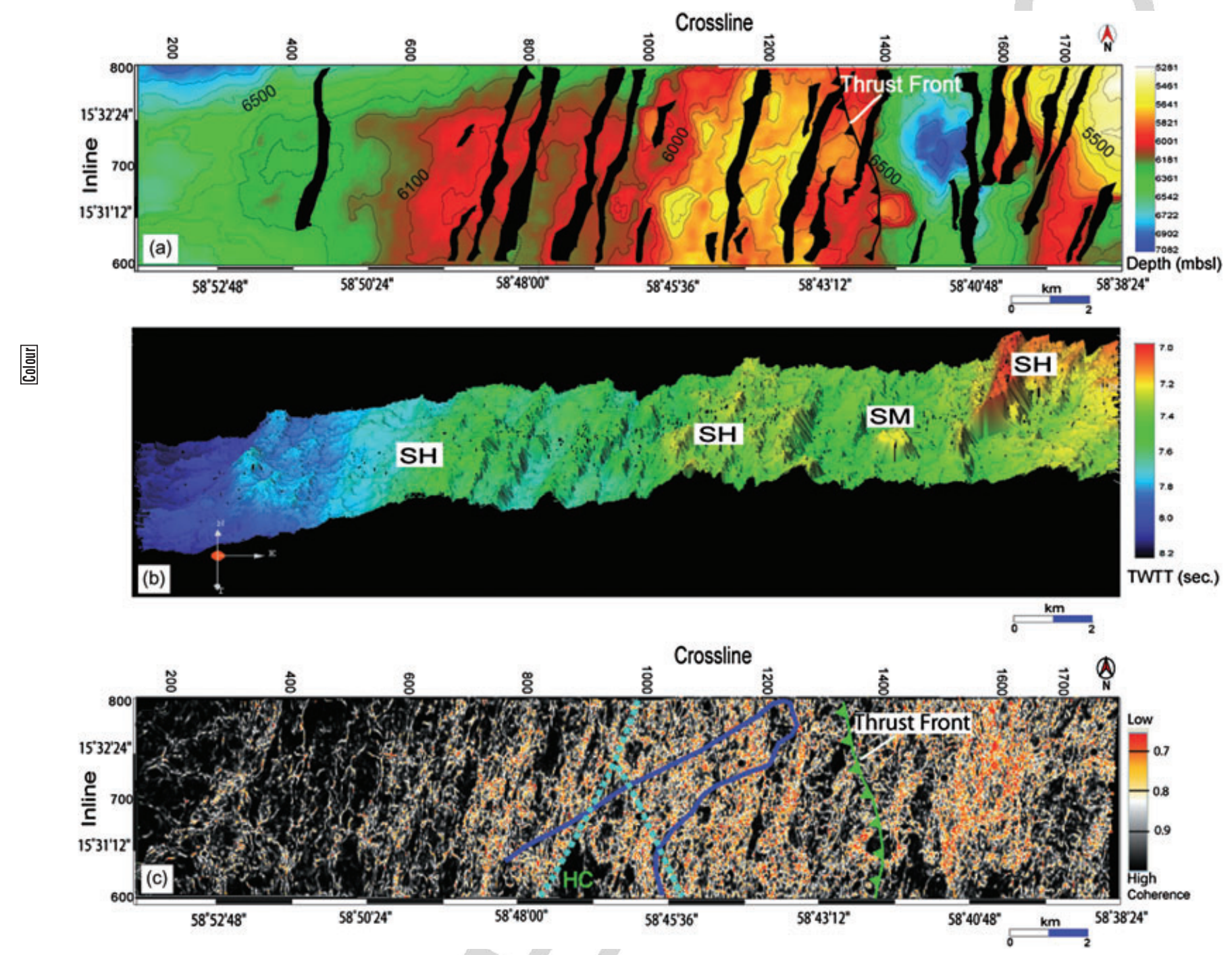

7 Fig. 9 (a) Depth, (b) 3D time surface (vertical exaggeration 4x), and (c) coherence of the top of the subducting oceanic basement. The outline of the northeast-trending band of strong negative amplitude in the décollement and the triangular-shaped quiet area in the seafloor are also shown in the coherence map. The oceanic basement is dominated by NNE-trending normal faults. The 3D surface of the oceanic basement reveals structural highs and seamounts. The coherence shows a small high-coherence area $(\mathrm{HC})$ below the northeast-trending band in the décollement. mbsl, meters below sealevel; SH, structural high; SM, seamount; TWTT, two-way travel time.

$$
\begin{aligned}
s(w) & =R M S(w) \\
& =\frac{1}{n_{w}} \sum_{i=1}^{n_{w}} \sqrt{\frac{1}{m_{i}-2} \sum_{j \in w_{i}}\left(z_{j}-\bar{z}\right)^{2}}
\end{aligned}
$$

where $n_{w}$ is the total number of windows of length $w, m_{i}$ is the number of points in window, $w_{i}$ and $z_{j}$ are the residuals on the trend, and $\bar{z}$ is the mean residual in window $w_{i}$.

\section{Estimation of fractal parameters}

$D$ and $A$ of the depth profiles of the décollement and top of the oceanic basement for seven inlines (C) 2009 The Authors Journal compilation (c) 2009 Blackwell Publishing Asia Pty Ltd
$(630,650,670,700,720,750,770)$ were computed (Table 4). Figure 11 shows the depth profiles of the décollement and top of the oceanic basement along inline 630 . The horizontal length of these profiles is over $18000 \mathrm{~m}$. The roughness profiles of the décollement and top of the oceanic basement were measured at intervals of $15 \mathrm{~m}$ and thus each profile has 1134 data points. We chose $100 \mathrm{~m}$ for the unit for $w$, then the data density $d$ of the roughness profiles is 6.67 , which is greater than the required value of 5.1 (Kulatilake \& Um 1999). For this data density value, a suitable $w$ is between $2.5 \%$ and $10 \%$ of the profile length (Kulatilake \& Um 1999). To be on the conservative side, $w$ values were 


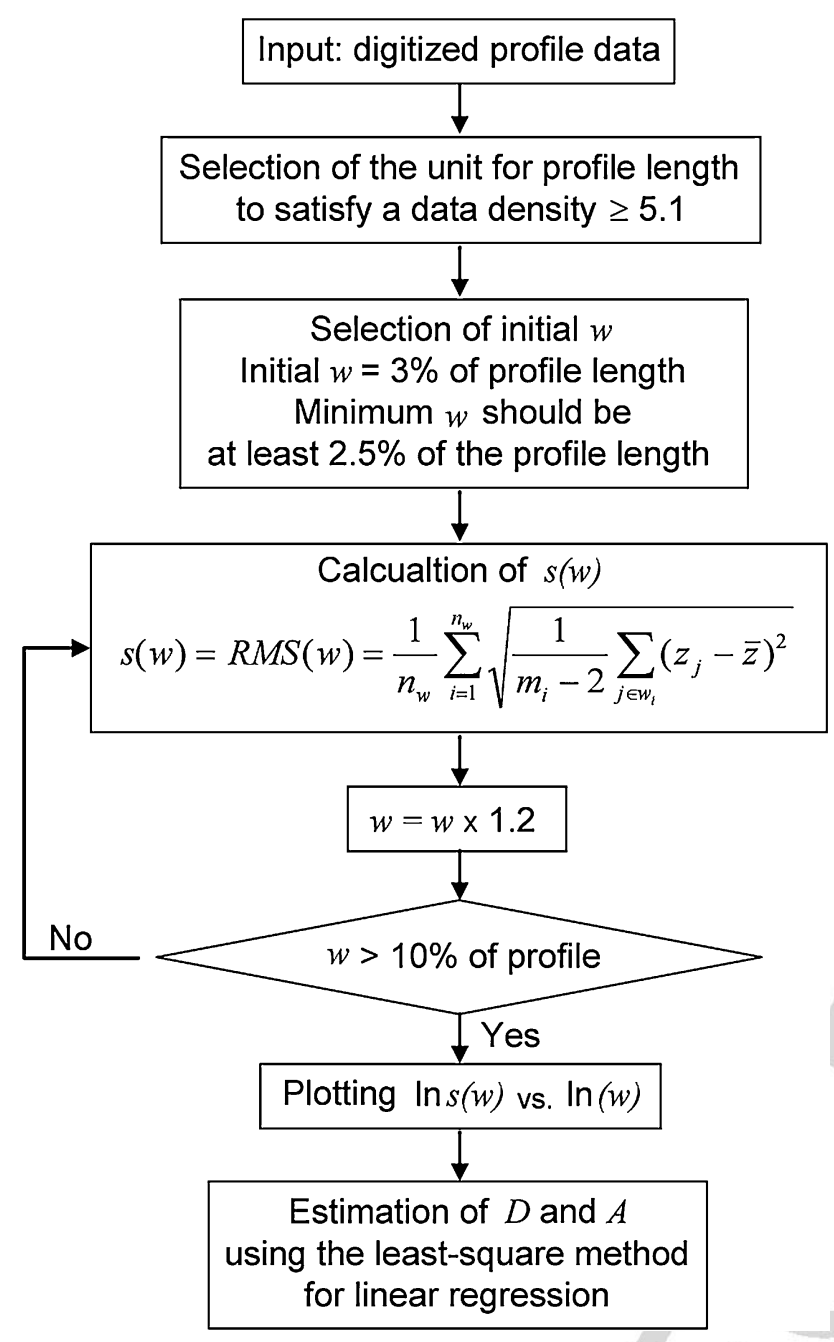

8 Fig. 10 Flow chart illustrating the procedure to compute fractal parameters $D$ and $A$ for the décollement and top of the oceanic basement.

chosen between $3 \%(500 \mathrm{~m})$ and $7 \%(1200 \mathrm{~m})$ of the profile length.

The $D$ and $A$ values for the depth profiles of the décollement and top of the oceanic basement are plotted for the inline numbers (Fig. 12). The $D$ values of the décollement and top of the oceanic basement in the southernmost inline 630 are greater than those of other inlines. Overall, the differences in $D$ values between the décollement and top of the oceanic basement are very small $(<0.042)$ for all inlines. On the other hand, the differences of the $A$ values or the amplitude of the roughness between the décollement and top of the oceanic basement are large $(>0.6)$. The correlation coefficients, $R$, for linear regression between $\ln s(w)$ and $\ln w$ values are greater than 0.9 for all inlines (Table 4).
Table 4 Fractal parameters of the décollement and top of oceanic basement computed by the roughness-length method (Malinverno 1990) and correlation coefficient for linear regression between $\ln s(w)$ and $\ln w$

\begin{tabular}{llccc}
\hline Inline no. & Depth profile & $D$ & $A$ & $R$ \\
\hline 630 & Décollement & 1.3570 & -1.9902 & 0.99 \\
& Basement & 1.3821 & -1.2341 & 0.97 \\
650 & Décollement & 1.2712 & -2.0694 & 0.99 \\
& Basement & 1.2655 & -1.3174 & 0.99 \\
670 & Décollement & 1.2154 & -2.0482 & 0.99 \\
& Basement & 1.2569 & -1.3642 & 0.99 \\
700 & Décollement & 1.2460 & -2.0599 & 0.97 \\
& Basement & 1.2901 & -1.3696 & 0.99 \\
720 & Décollement & 1.2446 & -2.0546 & 0.99 \\
& Basement & 1.2108 & -1.3998 & 0.99 \\
750 & Décollement & 1.2540 & -2.0488 & 0.99 \\
& Basement & 1.2214 & -1.3468 & 1.00 \\
770 & Décollement & 1.2509 & -1.9854 & 0.96 \\
& Basement & 1.2527 & -1.4133 & 0.98 \\
& & & & \\
\hline
\end{tabular}

$D, A$, fractal parameters; $R$, correlation coefficient; $s(w)$, standard deviation of the profile height; $w$, spanning length of the profile.

Differences in $D$ values between the décollement and top of the oceanic basement are very small $(<0.042)$, indicating the close correlation between two surfaces. High $R$ values indicate a strong linearity between $\ln w$ and $\ln s(w)$.

\section{DISCUSSION}

The dominant structural process at the toe of the accretionary prism is imbricate thrusting. The seafloor expression of the thrusts in the study area is revealed by the amplitude and coherence of the seafloor. The seafloor of the accretionary prism near the thrust front exhibits north- and NNWtrending lineations, reflecting the current westward convergence along the thrust front. On the other hand, those in the western part of the area show largely NNE-trending lineations. Zhao et al. (2000), based on 3D seismic inversion, suggested that the southward increase in density and thus strength of the proto-décollement zone continues into the décollement. Zhao et al. (2000) further proposed that a stronger décollement zone is responsible for a larger prism taper, thus more horizontal shortening, in the southern part of the prism toe. This, coupled with a thinner sediment unit above the proto-décollement, may have caused a relative retreat of the thrust front and the NNE-trending thrust. However, if the strength of the décollement zone had been responsible for the apparent, increased shortening of the prism in the southern part of the area, the NNE-trending thrusts would continue into the present frontal edge of the prism. The orientation of the thrusts instead changed abruptly from NNE to north and NNW toward the 


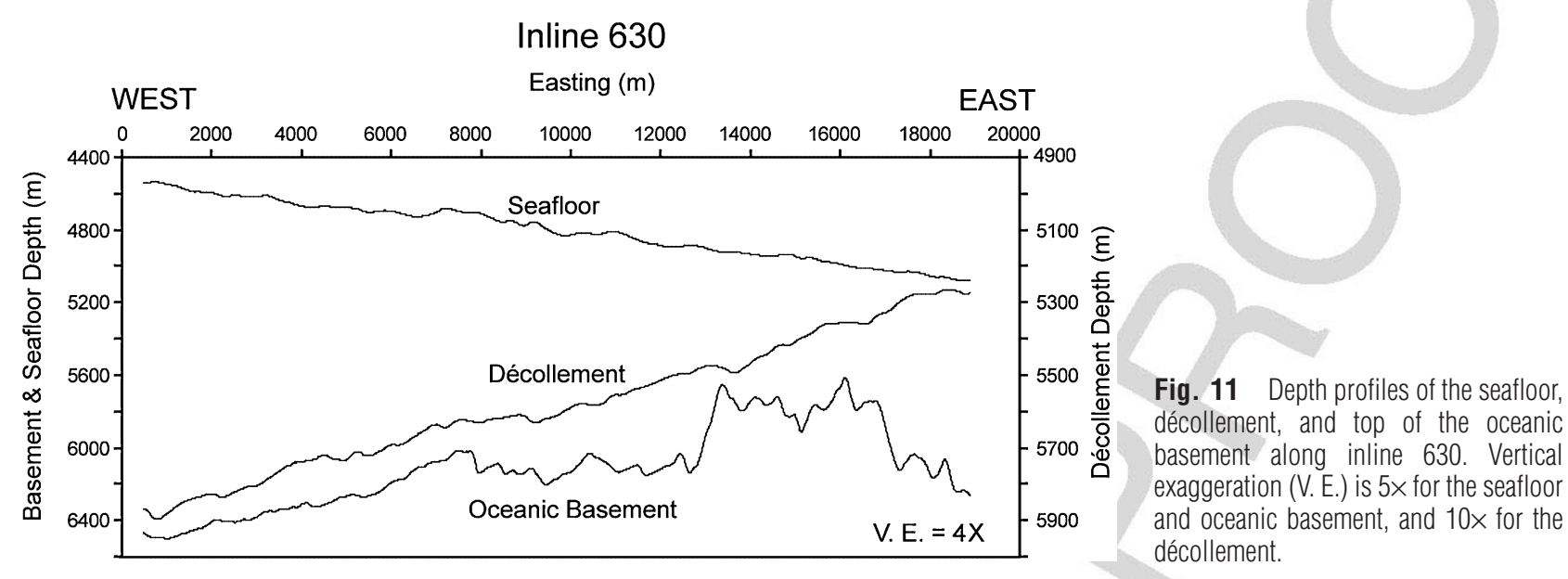

(a)

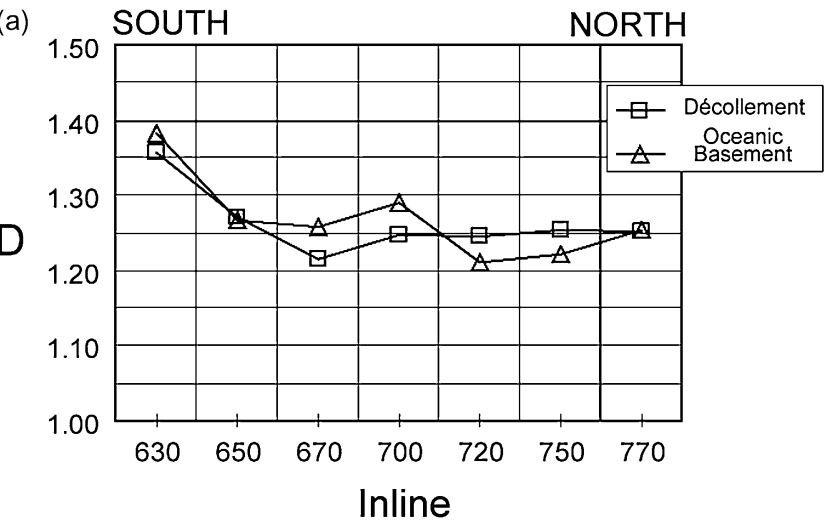

(b)

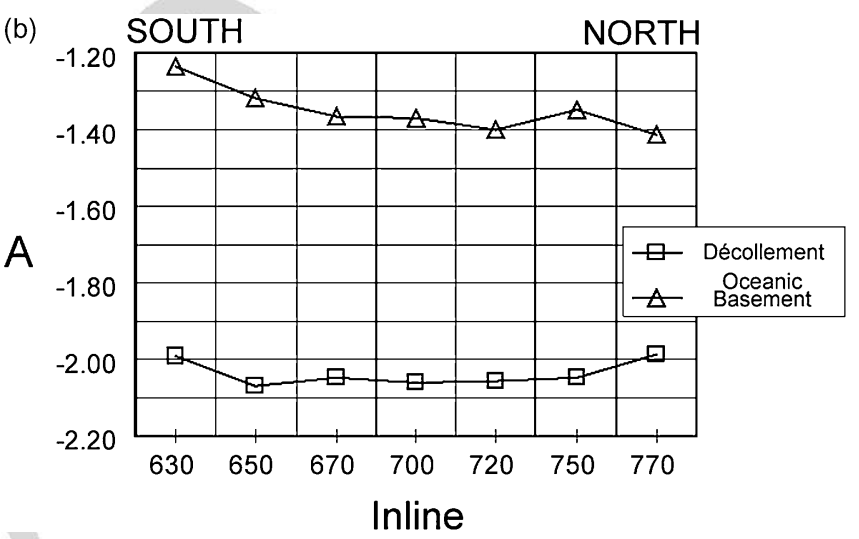

Fig. 12 Fractal parameters (a) $D$ and (b) $A$ of the décollement and top of the oceanic basement of six selected inlines. Very small differences $(<0.042)$ of the $D$ values between the décollement and top of the oceanic basement indicate the close correlation between two surfaces. The much smaller $A$ values of the décollement compared to those of the top of the oceanic basement indicate small roughness of the décollement.

frontal edge of the prism. The triangular-shaped quiet area between these two thrust sets may suggest a zone of relatively high porosity and low density and thus low strength, which did not readily facilitate thrusting in the accretionary prism. The line that forms the western boundary of the triangular-shaped area may represent the old thrust front. The southern part of this paleo-thrust front may have been retreated landward without significant internal deformation while its northern part experienced thrusting, resulting in the NNEtrending imbrication. Alternatively, the change in the thrust orientation may be due to changes in the direction of convergence along the thrust front. However, it is difficult to determine whether the NNE-trending thrusts are pervasive or local because of the very limited north-south data coverage.

The amplitude map of the décollement in the present study is different from those of previous studies (Shipley et al. 1994, 1997; DiLeonardo et al. 2002), in that the décollement reflection is dominantly of negative polarity. Shipley et al. (1994, their figure 3) identified small areas of positive polarity in the décollement. These small anomalous areas are not obvious in the amplitude map of the décollement by DiLeonardo et al. (2002, their figure 3), which shows much larger areas of positive amplitude, covering over 50\% of the décollement. The seismic profiles with the negative-polarity to positive-polarity transition toward the areas with positive décollement reflection in Shipley et al. (1994, their figure 2) and DiLeonardo et al. (2002, their figure 2) show that the negative polarity and the positive polarity are separated by a zone of degraded seismic signal. However, the trough of the negative-polarity décollement, although the amplitude is reduced and the post-cursor peak of this reduced-amplitude trough is weak, appears to continue beneath the peak, which was interpreted as the décollement by Shipley et al. (1994) and DiLeonardo et al. (2002). 


\section{5}

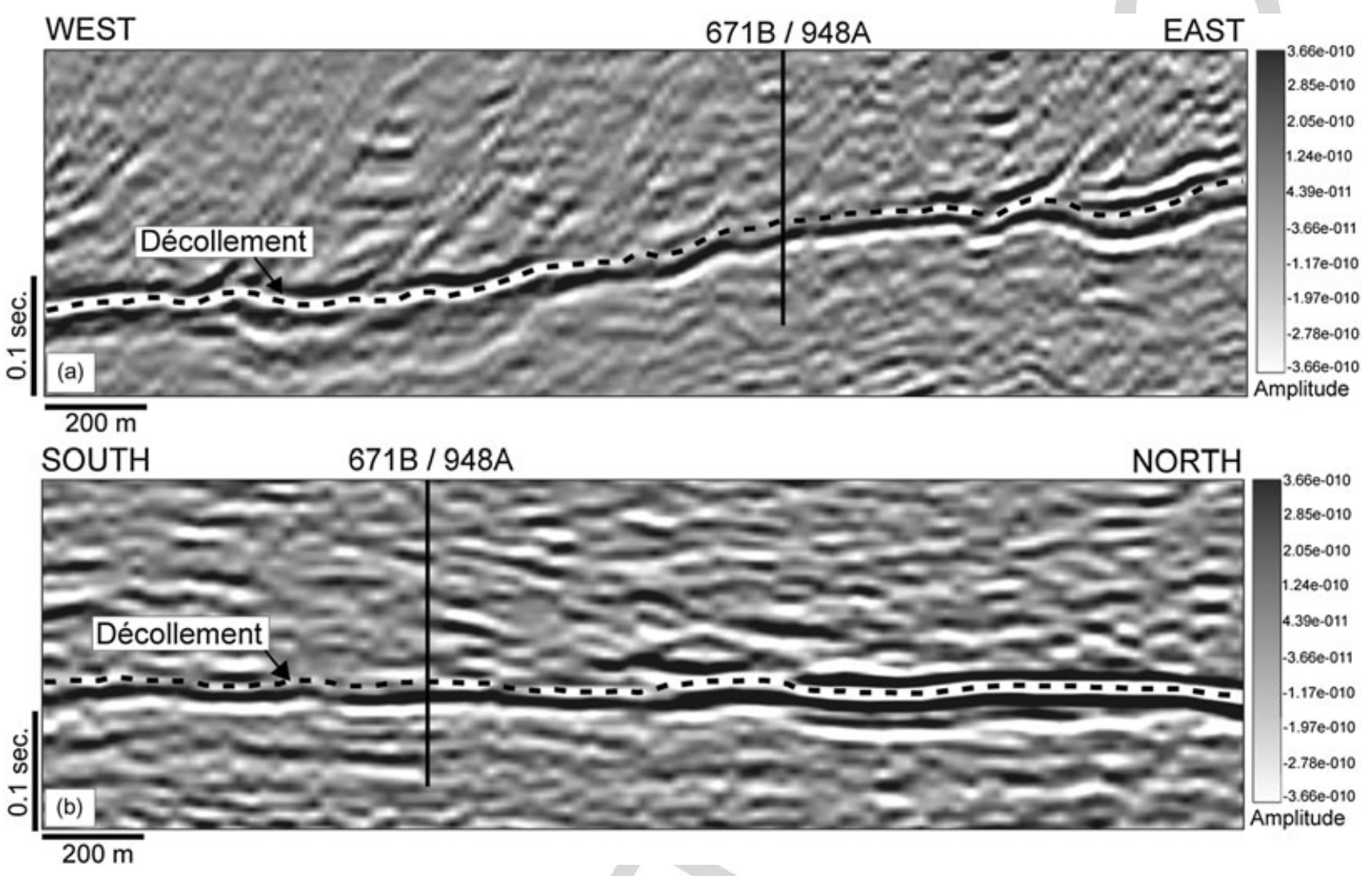

Fig. 13 Segments of (a) inline and (b) crossline traversing Ocean Drilling Program (ODP) holes 671B/948A, previously interpreted to have a positive-polarity décollement reflection. Transition from negative to positive polarity in the décollement reflection toward ODP holes 671/948A is not evident; instead, the negative polarity décollement can be followed across the profiles. Figure 2 shows location.

The negative-polarity to positive-polarity transition toward the areas with positive décollement reflection is also not evident in inlines and crosslines (Fig. 13) traversing 671B/948A, located in the area supposedly with the positive-polarity décollement reflection. The negative-polarity décollement reflection can be followed across the profiles traversing $671 \mathrm{~B} / 948 \mathrm{~A}$ without disruption.

The polarity transition in the décollement is also identified in this study but it is seen only very locally. Areas of positive-polarity décollement reflection in our amplitude map are very small and not as distinct as those of Shipley et al. (1994). The negative-polarity to positive-polarity transition toward the areas with positive décollement reflection has been attributed to an increase in velocity and density (Shipley et al. 1994). The acoustic impedance of the weak, fluid-rich décollement zone is likely to be less than that of the accretionary prism, and therefore, the polarity of the décollement reflection would be dominantly negative. The accurate interpretation of the polarity and thus the amplitude of the décollement is very important because the seismic amplitude varia- tions of the décollement may signify differing fluid regimes and stress states (Shipley et al. 1994, 1997; Bangs et al. 1996, 1999). Changes in physical properties and thickness of the décollement can further cause amplitude changes. Physical properties of the rocks above and below the décollement also vary spatially, giving rise to amplitude changes of the décollement.

The northeast-trending bright spot-like amplitude band apparently with reduced density is the exception to the landward densification along the décollement (Moore 2000). This amplitude band is interpreted as an interval of arrested consolidation (Moore et al. 1998; Bangs et al. 1999), which may be due to the reduction of permeability in the décollement zone conduit (Moore 2000). The density and porosity maps of the proto-décollement zone, predicted from seismic inversion, suggest that the low-density feature in the décollement was inherited from that of the proto-décollement, enhanced further by localized arrested consolidation after subduction (Zhao et al. 2000). DiLeonardo et al. (2002) suggested that the northeast-trending amplitude band in the décollement is controlled by Journal compilation @ 2009 Blackwell Publishing Asia Pty Ltd 

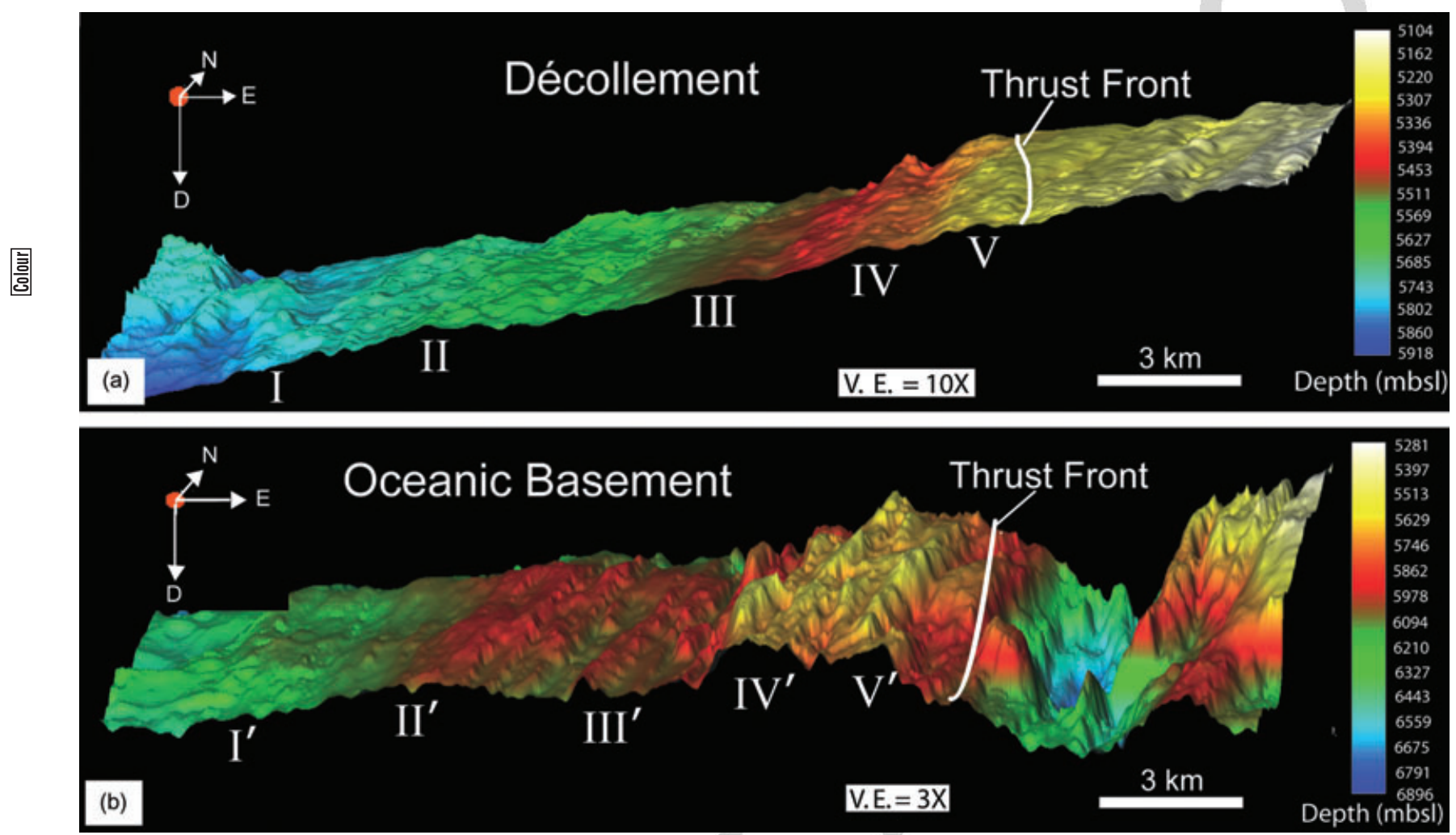

Fig. 14 (a) Three-dimensional surfaces of the décollement (vertical exaggeration, V. E. 10x) and (b) the top of the oceanic basement (V. E. 3x). Subtle highs $(I-V)$ in the décollement can be correlated with prominent structural highs $\left(I^{\prime}-V^{\prime}\right)$ in the oceanic basement. mbsl, meters below sealevel.

arc-oblique, northeast-trending strike-slip faults that cut across the incoming oceanic plate and extend beneath the accretionary prism. A large part of the northeast-trending amplitude band overlaps the triangular-shaped quiet area in the accretionary prism, suggesting that the arrested consolidation may be at least in part due to the lack of thrust imbrication and thus vertical drainage for fluid.

Wallace et al. (2003) showed that surface relief increases from the proto-décollement to the décollement in the study area and that statistically significant variances of the décollement and basement horizons collocate, indicating that the roughness of the décollement is influenced by the structural trends of the oceanic basement. Large basement faults in the study area cut the underthrust sediment and extend to the small bumps or steps in the décollement, suggesting that these faults are penetrative. The very small differences in the fractal parameter $D$ between the décollement and top of the oceanic basement confirm the correlation between the roughness or relief of the décollement and the topography of the oceanic basement. The high $R$ values further indicate a strong linearity between $\ln w$ and $\ln s(w)$. The

(C) 2009 The Authors

Journal compilation @ 2009 Blackwell Publishing Asia Pty Ltd roughness of the décollement is not as significant as that of the oceanic basement, as indicated by the much smaller $A$ values of the décollement compared to those of the top of the oceanic basement. Figure 14 shows the 3D surfaces of the décollement (vertical exaggeration $10 \times$ ) and top of the oceanic basement (vertical exaggeration $3 \times$ ). The minor highs $(\mathrm{I}-\mathrm{V})$ in the décollement can be correlated with the structural highs $\left(\mathrm{I}^{\prime}-\mathrm{V}^{\prime}\right)$ in the oceanic basement.

Structures in the underthrust sedimentary section appear to be mostly secondary, formed by differential compaction (Zhao et al. 1998) and controlled by structures in the oceanic basement. The lateral variations of the thickness of the underthrust sediment, filling the horst-and-graben topography of the underlying oceanic basement, probably led to differential compaction. Differential compaction of the underthrust sedimentary sequences, together with the basement faults that penetrate into the décollement, may have caused relief or even faulting in the décollement, affecting the fluid flow across the décollement. Strike-slip faults in the oceanic basement (DiLeonardo et al. 2002) may also have enhanced the relief of the décollement. 


\section{SUMMARY AND CONCLUSIONS}

1. The amplitude and coherence of the seafloor show two sets of faults: (i) NNE-trending thrusts west of the deformation front; and (ii) north- and NNW-trending thrusts near the front, separated by the triangular-shaped quiet area.

2. The triangular-shaped quiet area may represent a zone of low strength (high porosity and low density) and thus of little brittle deformation in the accretionary prism.

3. The northeast-trending, anomalous amplitude and coherence band in the décollement, interpreted as an interval of arrested consolidation, overlaps the triangular-shaped quiet area, suggesting that the arrested consolidation may be related to the lack of thrust imbrication and thus vertical drainage for fluid in the accretionary prism.

4. Some large faults in the basement extend to the small bumps or steps in the décollement, suggesting that these faults are penetrative, probably affecting the fluid flow in the accretionary prism.

5. The velocity field of the study area was created from LWD and 3D seismic data to construct the depth maps of the décollement and the top of the oceanic basement.

6. Fractal analysis of the spatial variations of the depth profiles of the décollement and top of the oceanic basement, using the roughness-length method, shows that the relief of the décollement, although very minor, correlates closely with the topography of the oceanic basement.

7. The differential compaction of the underthrust sediment and the basement faults, extending into the décollement, probably caused relief or even faulting in the décollement zone, affecting the fluid flow across the décollement.

\section{ACKNOWLEDGEMENTS}

We thank the Korea Integrated Ocean Drilling Program (K-IODP) for providing funding for this study. Suggestions and comments by J. Ashi greatly helped improve the manuscript. We also thank the Marine Seismic Data Center at the University of Texas Institute for Geophysics (UTIG) for providing the 3D seismic data set and the Ocean Drilling Program (ODP) data base for providing logging-while-drilling (LWD) data.
Kingdom Suite ${ }^{\circledR}$, OpendTect ${ }^{\circledR}$, and HampsonRussell $^{\circledR}$ were used for seismic and well-log data analysis and mapping.

\section{REFERENCES}

Asquith G. 1982. Basic Well Log Analysis for Geologists. American Association of Petroleum Geologists, Tulsa, OK.

BAHORICH M. S. \& FARMER S. L. 1995. 3D seismic coherency for faults and stratigraphic features. Leading Edge 14, 1053-8.

BANGS N. L., WeSTBRoOK G. K., LADD J. \& BUhL P. 1990. Seismic velocities from the Barbados Ridge Complex: Indicators of high pore fluid pressures in an accretionary complex. Journal of Geophysical Research 95, 8767-82.

Bangs N. L., Shipley T. H. \& Moore G. F. 1996. Elevated fluid pressure and fault zone dilatation inferred from seismic models of the northern Barbados Ridge décollement. Journal of Geophysical Research 101, 627-42.

Bangs N. L., Shipley T. H., Moore J. C. \& Moore G. G. 1999. Fluid accumulation, and channeling along the northern Barbados Ridge décollement. Journal of Geophysical Research 104, 20 399-414.

BiJu-Duval B., Lequellec P., Mascle A., Renard V. \& VALERY P. 1982. Multibeam bathymetric survey and high resolution seismic investigations on the Barbados ridge complex (eastern Caribbean): A key to the knowledge and interpretation of an accretionary wedge. Tectonophysics 86, 275-304.

Capet X., Chamley H., Beck C. \& Holtapfel T. 1990. Clay mineralogy of sites 671 and 672, Barbados accretionary complex and Atlantic abyssal plain: Paleoenvironmental and diagenetic implications. In Moore J. C., Mascle A. \& Taylor E. et al. (eds.) Proceedings of the Ocean Drilling Program, Scientific Results, pp. 85-96. Ocean Drilling Program, College Station, TX.

Dileonardo C. G., Moore J. C., Nissen S. \& Bangs N. 2002. Control of internal structure and fluidmigration pathways within the Barbados Ridge décollement zone by strike-slip faulting: Evidence from coherence and three-dimensional seismic amplitude imaging. Geological Society of America Bulletin 114, $51-63$.

Dixon T. H., Farina F., Demets C., Jansma P., ManN P. \& CALAis E. 1998. Relative motion between the Caribbean, and North American plates, and related boundary zone deformation from a decade of GPS observations. Journal of Geophysical Research 103, $15157-82$.

ERICKSON S. N. \& JARRARD R. D. 1999. Porosityformation factor and porosity-velocity relationships in Barbados Prism. Journal of Geophysical Research 104, 15 391-407. 
Feder J. 1988. Fractals. Plenum Press, New York. Kulatilake P. H. S. W. \& UM J. 1999. Requirements for accurate quantification of self-affine roughness using the roughness-length method. International Journal of Rock Mechanics and Mineral Science \& Geomechanics 36, 5-18.

LePichon X., Henry P. \& Lallemant S. 1993. Accretion and erosion in subduction zones: The role of fluids. Annual Review of Earth and Planetary Science 21, 308-31.

MALINVERNo A. 1990. A simple method to estimate the fractal dimension of a self affine series. Geophysical Research Letters 17, 1953-6.

Moore G. F. \& ShIPley T. H. 1988. Behavior of the decollement at the toe of the Middle America Trench. Geologische Rundschau 77, 275-84.

Moore G. F., Zhao Z., Shipley T. H., Bangs N. L. B. \& Moore J. C. 1995. Structural setting of the leg 156 area, Northern Barbados Ridge accretionary prism. In Shipley T. H., Ogawa Y., Blum P. et al. (eds.) Proceedings of the Ocean Drilling Program, Initial Reports, pp. 13-27. Ocean Drilling Program, College Station, TX.

Moore G. F., ZhaO Z. \& SHIPley T. H. 1997. Integration of vertical seismic profiling, logging, and seismic data in the vicinity of the decollement, northern Barbados Ridge accretionary prism. In Shipley T. H., Ogawa Y., Blum P. \& Bahr J. (eds.) Proceedings of the Ocean Drilling Program, Scientific Results, pp. 25562. Ocean Drilling Program, College Station, TX.

Moore J. C. 2000. Synthesis of results: Logging while drilling, northern Barbados accretionary prism. In Moore J. C. \& Klaus A. (eds.) Proceedings of the Ocean Drilling Program, Scientific Results, pp. ••-・.・, ••. (Online). [Cited 2 Dec 2007.] Available from: http://www-odp.tamu.edu/publications/171A_ SR/chap_03/chap_03.htm

Moore J. C. \& VRoLiJK P. 1992. Fluids in accretionary prisms. Reviews of Geophysics and Space Physics 30, 113-35.

Moore J. C., Shipley T. H., Goldberg D. \& OGaWA Y. 1995. Leg 156 Shipboard Scientific Party: Abnormal fluid pressures and fault-zone dilation in the Barbados accretionary prism: Evidence from logging while drilling. Geology 23, 605-8.

Moore J. C., Klaus A., Bangs N. L. et al. 1998. Consolidation patterns during initiation and evolution of a plate-boundary decollement zone: Northern Barbados accretionary prism. Geology 26, 811-14.

Peacock S., Westbrook G. K. \& Graham D. P. 1997. Seismic velocities in the northern Barbados Ridge accretionary complex, Site 949. In Shipley T. H., Ogawa Y., Blum P. \& Bahr J. (eds.) Proceedings of the Ocean Drilling Program, Scientific Results, pp. 26378. Ocean Drilling Program, College Station, TX.

SHIPBOARD SCIENTIFIC PARTY. 1988. Site 672. In Moore J. C., Mascle A. \& Taylor E. et al. (eds.) Proceedings of the Ocean Drilling Program, Initial
Reports, pp. 205-310. Ocean Drilling Program, College Station, TX.

SHIPBOARD SCIENTIFIC PARTy. 1995. Site 948, downhole logging. In Shipley T. H., Ogawa Y. \& Blum P. etal. (eds.) Proceedings of the Ocean Drilling Program, Initial Reports, pp. 57-92. Ocean Drilling Program, College Station, TX.

SHIPBOARD SCIENTIFIC PARTY. 1998. Introduction to logging-while-drilling investigations of faulting, fluid flow, and seismic images of the northern Barbados subduction zone. In Moore J. C., Klaus A. \& Bangs N. L. et al. (eds.) Proceedings of the Ocean Drilling Program, Initial Reports, pp. 5-10. Ocean Drilling Program, College Station, TX.

Shipley T. H., Moore G. F., Bangs N. L., Moore J. C. \& STOFFA P. L. 1994. Seismically inferred dilatancy distribution, northern Barbados Ridge décollement: Implications for fluid migration and fault strength. Geology 22, 411-14.

Shipley T. H., Moore G. F., Tobin H. \& Moore J. C. 1997. Synthesis of the Barbados décollement seismic reflection response from drilling-based geophysical observations and physical properties. In Shipley T., Ogawa Y., Blum P. \& Bahr J. M. (eds.) Proceedings of the Ocean Drilling Program, Scientific Results, pp. 293-302. Ocean Drilling Program, College Station, TX.

Shipley T. H., Bangs N. L. \& Henning A. T. 1998. Sediment velocity estimation using iterative $3-\mathrm{D}$ migrations of short offset seismic reflection data in deep water. Marine Geophysical Researches 20, 479-94.

Speed R., Westbrook G., Mascle A. et al. 1984. Lesser Antilles Arc and Adjacent Terranes: Woods Hole, Massachusetts. Ocean Margin Drilling Program, Regional Atlas Series, Atlas 10. Marine Science International, Woods Hole, MA.

SpeEd R. C. \& LARUE D. K. 1982. Barbados: Architecture and implications for accretion. Journal of Geophysical Research 87, 3633-43.

TheYs P. P. 1991. Log Data Acquisition and Quality Control. Editions Technip, Paris.

Tomblin J. F. 1975. The Lesser Antilles and Aves Ridge. In Nairn A. E. M. \& Stehli F. G. (eds.) Ocean Basins and Margins, pp. 467-500. Plenum Press, New York.

TRIBble J. S. 1990. Clay diagenesis in the Barbados Accretionary complex: Potential impact on hydrology and subduction dynamics. In Moore J. C., Mascle A. \& Taylor E. et al. (eds.) Proceedings of the Ocean Drilling Program, Scientific Results, pp. 97-100. Ocean Drilling Program, College Station, TX.

von Huene R. \& SCHOLL D. W. 1991. Observations at convergent margins concerning sediment subduction, subduction erosion, and the growth of continental crust. Reviews of Geophysics 29, 279-316.

Wallace G., Moore J. C. \& Dileonardo C. G. 2003. Controls on localization and densification of a modern 
décollement: Northern Barbados accretionary prism. Geological Society of America Bulletin 115, 288-97.

Westbrook G. K., Mascle A. \& BiJu-Duval B. 1984. Geophysics and structure of the Lesser Antilles forearc. In Biju-Duval B., Moore J. C. \& Bergen J. A. et al. (eds.) Proceedings of the Deep Sea Drilling Program, Initial Reports, pp. 631-5. ••, ・・.

Zhao Z., Moore G. F. \& Shipley T. H. 1998. Deformation and dewatering of the subducting plate beneath the lower slope of the northern Barbados accretionary prism. Journal of Geophysical Research 103, 431-49.

ZhaO Z., Moore G. F., Bangs N. L. \& Shipley T. 2000. Spatial variations of the décollement/protodécollement zone and their implications: A 3-D seismic inversion study of the Northern Barbados accretionary prism. Island Arc 9, 219-36. 


\begin{tabular}{|l|l|}
\hline \multicolumn{2}{|c|}{ SNP Best-set Typesetter Ltd. } \\
\hline Journal Code: IAR & Proofreader: Mony \\
\hline Article No: 679 & Delivery date: 8 June 2009 \\
\hline Page Extent: 19 & \\
\hline
\end{tabular}

\section{AUTHOR QUERY FORM}

Dear Author

During the preparation of your manuscript, the questions listed below have arisen. Please answer all the queries (marking any other corrections on the proof enclosed) and return this form with your proofs.

\begin{tabular}{|c|c|c|}
\hline $\begin{array}{l}\text { Query } \\
\text { References }\end{array}$ & Query & Remarks \\
\hline$q 1$ & $\begin{array}{l}\text { AUTHOR: Please supply the name of the publisher and the city } \\
\text { location of publisher for this chapter in Westbrook et al., } 1984 \text {. }\end{array}$ & \\
\hline q2 & $\begin{array}{l}\text { WILEY-BLACKWELL: Fig. } 14 \text { Please either amend or replace } \\
\text { Figure 14(b). Author has sent an amended figure to } \\
\text { Yuko.Fukuda@wiley.com, and copyeditor has made a comment on the } \\
\text { acrobat file to request an amendment. }\end{array}$ & \\
\hline q3 & $\begin{array}{l}\text { AUTHOR: Figure } 3 \text { has been saved at a low resolution of } 278 \text { dpi. Please } \\
\text { resupply at } 300 \text { dpi. Please check required artwork specifications at } \\
\text { http://www.blackwellpublishing.com/authors/digill.aspi. }\end{array}$ & \\
\hline q4 & $\begin{array}{l}\text { AUTHOR: Figure } 4 \mathrm{ab} \text { is of poor quality (label is blurry). Please check } \\
\text { required artwork specifications at http://www.blackwellpublishing. } \\
\text { com/authors/digill.aspi. }\end{array}$ & \\
\hline q5 & $\begin{array}{l}\text { AUTHOR: Figure } 7 \text { is of poor quality (label is blurry). Please check } \\
\text { required artwork specifications at http://www.blackwellpublishing. } \\
\text { com/authors/digill.aspi. }\end{array}$ & \\
\hline$q 6$ & $\begin{array}{l}\text { AUTHOR: Figure } 8 \text { is of poor quality (label is blurry). Please check } \\
\text { required artwork specifications at http://www.blackwellpublishing. } \\
\text { com/authors/digill.aspi. }\end{array}$ & \\
\hline q7 & $\begin{array}{l}\text { AUTHOR: Figure } 9 \text { is of poor quality (label is blurry). Please check } \\
\text { required artwork specifications at http://www.blackwellpublishing. } \\
\text { com/authors/digill.aspi. }\end{array}$ & \\
\hline q8 & $\begin{array}{l}\text { AUTHOR: Figure } 10 \text { is of poor quality (label is blurry). Please check } \\
\text { required artwork specifications at http://www.blackwellpublishing. } \\
\text { com/authors/digill.aspi. }\end{array}$ & \\
\hline q9 & $\begin{array}{l}\text { AUTHOR: Figure } 11 \text { has been saved at a low resolution of } 261 \mathrm{dpi} \text {. Please } \\
\text { resupply at } 300 \text { dpi. Please check required artwork specifications at } \\
\text { http://www.blackwellpublishing.com/authors/digill.aspi. }\end{array}$ & \\
\hline q10 & $\begin{array}{l}\text { AUTHOR: Figure } 12 \text { has been saved at a low resolution of } 207 \text { dpi. Please } \\
\text { resupply at } 300 \text { dpi. Please check required artwork specifications at } \\
\text { http://www.blackwellpublishing.com/authors/digill.aspi. }\end{array}$ & \\
\hline q11 & $\begin{array}{l}\text { AUTHOR: Figure } 13 \text { has been saved at a low resolution of } 214 \mathrm{dpi} \text {. Please } \\
\text { resupply at } 300 \text { dpi. Please check required artwork specifications at } \\
\text { http://www.blackwellpublishing.com/authors/digill.aspi. }\end{array}$ & \\
\hline
\end{tabular}



resupply at $300 \mathrm{dpi}$. Please check required artwork specifications at http://www.blackwellpublishing.com/authors/digill.aspi. 